\title{
Distinct Localization of P2X Receptors at Excitatory Postsynaptic Specializations
}

\author{
Maria E. Rubio and Florentina Soto \\ Department of Molecular Biology of Neuronal Signals, Max-Planck-Institute for Experimental Medicine, D-37075 \\ Göttingen, Germany
}

\begin{abstract}
ATP mediates fast excitatory synaptic transmission in some regions of the central nervous system through activation of $\mathrm{P} 2 \mathrm{X}$ receptors. Nonetheless, the functional significance of ATPmediated neurotransmission is not yet understood. Using postembedding immunocytochemistry, we describe the distribution of $\mathrm{P} 2 \mathrm{X}_{2}, \mathrm{P} 2 \mathrm{X}_{4}$, and $\mathrm{P} 2 \mathrm{X}_{6}$ subunits in cerebellum and in the CA1 region of the hippocampus. Dendritic spines of cerebellar Purkinje cells showed immunogold labeling for all three subunits when apposed to parallel fiber (PF) terminals. In contrast, no immunogold labeling was observed on dendritic spines or cell bodies receiving inputs from climbing fibers and basket cells, respectively. In CA1 pyramidal cells, postsynaptic membranes apposed to terminals of Schaffer collaterals were immunogold-labeled for $\mathrm{P}_{2} \mathrm{X}_{2}, \mathrm{P}_{2} \mathrm{X}_{4}$, and $\mathrm{P} 2 \mathrm{X}_{6}$ subunits. Immunolabeling was also observed perisynaptically and intracel-
\end{abstract}

lularly in relation to membranes of the endoplasmic reticulum. The analysis of the tangential distribution of gold particles showed that they were preferentially located at the peripheral portion of the postsynaptic specialization of both parallel fiber and Schaffer collateral synapses. By double imunogold labeling using antibodies for P2X receptor subunits and GluR2/3 subunits of the AMPA glutamate receptors, we show that synapses expressing P2X receptors are also glutamatergic. The present study shows for the first time qualitatively and quantitatively the precise localization of $\mathrm{P} 2 \mathrm{X}$ receptors in brain. Moreover, our data indicate that $\mathrm{P} 2 \mathrm{X}$ receptors may play a significant role at glutamatergic synapses.

Key words: ATP; P2X receptors; ligand-gated ion channels; excitatory synapses; cerebellum; hippocampus; postembedding immunocytochemistry
The first indication of a transmitter role for ATP in the nervous system was presented 40 years ago, with the demonstration of ATP release from sensory nerves during antidromic stimulation (Holton, 1959). It is now well accepted that ATP is involved in cell to cell communication in the peripheral nervous system (for review, see Dubyak and el-Moatassim, 1993; Burnstock, 1999). However, ATP-mediated fast neurotransmission has only recently been described in the CNS, where its role is not yet well understood (Edwards et al., 1992; Bardoni et al., 1997; Nieber et al., 1997; Pankratov et al., 1998, 1999; for review, see Robertson, 1998).

Fast responses to extracellular ATP are mediated by the activation of $\mathrm{P} 2 \mathrm{X}$ receptors. Seven members of this family of ligandgated ion channels have been cloned $\left(\mathrm{P}_{2} \mathrm{X}_{1}-\mathrm{P} 2 \mathrm{X}_{7}\right)$ (North and Barnard, 1997; Soto et al., 1997). Native and cloned P2X receptors are permeable to monovalent cations such as $\mathrm{Na}^{+}$and $\mathrm{K}^{+}$as well as divalent cations such as $\mathrm{Ca}^{2+}$ (Burnashev, 1998). In contrast to NMDA receptors, influx of $\mathrm{Ca}^{2+}$ through $\mathrm{P} 2 \mathrm{X}$ recep-

\footnotetext{
Received June 12, 2000; revised Oct. 3, 2000; accepted Oct. 23, 2000.

M.E.R. is supported by the Alexander von Humboldt Foundation. We are grateful to Prof. W. Stühmer for support, lab space, equipment, and reading of this manuscript. We thank Dr. R. J. Wenthold for valuable comments on this manuscript and for helping with the generation of the antibodies for $\mathrm{P} 2 \mathrm{X}_{2}$ and $\mathrm{P} 2 \mathrm{X}_{4}$. We acknowledge the expert technical assistance of K. Borchardt. We thank Dr. R. J. Wenthold and Prof. A. Surprenant for kindly providing us with the antibody for GluR $2 / 3$ subunits and the HEK-293 cells transfected with $\mathrm{P}_{2} \mathrm{X}_{1}$ and $\mathrm{P} 2 \mathrm{X}_{2}$, respectively. We acknowledge Dr. Martin Stocker for technical advice on the purification of GSTfusion proteins and Dr. Luis Pardo for his great help with the confocal microscope. Additionally, we thank D. Kerschensteiner for valuable scientific discussion and critical reading of this manuscript.

Correspondence should be addressed to Dr. Maria E. Rubio, Max-Plank-Institute for Experimental Medicine, Department of Molecular Biology of Neuronal Signals, Hermann-Rein Strasse 3, D-37075 Göttingen, Germany. E-mail:mrubio@gwdg.de. Copyright (C) 2001 Society for Neuroscience $0270-6474 / 01 / 210641-13 \$ 15.00 / 0$
}

tors occurs at the resting potential of the neuron, providing an additional source of $\mathrm{Ca}^{2+}$ entry that could modulate the performance of the postsynaptic cell (Edwards and Gibb, 1993).

Of the seven cloned $\mathrm{P} 2 \mathrm{X}$ subunits, only $\mathrm{P} 2 \mathrm{X}_{4}$ and $\mathrm{P} 2 \mathrm{X}_{6}$ mRNA transcripts are widely distributed with overlapping patterns in rat brain (Collo et al., 1996; Soto et al., 1996a,b). Light microscopy using an antibody against $\mathrm{P} 2 \mathrm{X}_{4}$ confirmed these results (Lê et al., 1998b). The distribution of $\mathrm{P}_{2} \mathrm{X}_{6}$ protein in the brain is unknown. mRNA and protein expression for $\mathrm{P} 2 \mathrm{X}_{2}$ in adult rat brain were originally found in a subset of neurons (Kidd et al., 1995; Collo et al., 1996; Vulchanova et al., 1996). In particular, no expression was detected in areas where $\mathrm{P} 2 \mathrm{X}_{4}$ and $\mathrm{P} 2 \mathrm{X}_{6}$ subunits were present at high levels, such as cerebellum and hippocampus. However, recent work (Kanjhan et al., 1999) supports the notion that the distribution of $\mathrm{P} 2 \mathrm{X}_{2}$ receptor subunits is as extended in brain as that described for $\mathrm{P} 2 \mathrm{X}_{4}$ and $\mathrm{P} 2 \mathrm{X}_{6}$ subunits.

To elucidate the role of ATP as a neurotransmitter in the CNS, the subcellular distribution of the three predominant $\mathrm{P} 2 \mathrm{X}$ receptor subunits $\left(\mathrm{P} 2 \mathrm{X}_{2}, \mathrm{P} 2 \mathrm{X}_{4}\right.$, and $\left.\mathrm{P} 2 \mathrm{X}_{6}\right)$ in rat brain was analyzed by postembedding immunogold labeling. The analysis was performed in cerebellum and hippocampus for the following reasons: (1) These two regions express all three P2X subunits. (2) Fast synaptic currents mediated by ATP have been detected in the CA1 region of the hippocampus (Pankratov et al., 1998, 1999), and cultured cerebellar Purkinje cells respond to ATP with an increase in intracellular $\mathrm{Ca}^{2+}$ evoked by activation of $\mathrm{P} 2 \mathrm{X}$ receptors (Mateo et al., 1998). (3) Hippocampal pyramidal neurons and cerebellar Purkinje cells have well described synaptic circuitry. Our results show the presence of $\mathrm{P} 2 \mathrm{X}$ receptor subunits at excitatory postsynaptic specialization of Schaffer collaterals in hippocampus CA1 and parallel fibers (PFs) in cerebellum. Im- 
munolabeling for $\mathrm{P} 2 \mathrm{X}$ receptor subunits was mainly found at the periphery of the postsynaptic specialization. The physiological relevance of this is discussed.

\section{MATERIALS AND METHODS}

Antibodies. Antibodies to the $\mathrm{C}$ terminus of $\mathrm{P} 2 \mathrm{X}_{2}$ and $\mathrm{P} 2 \mathrm{X}_{4}$ were generated using a synthetic peptide corresponding to the following sequences: $\mathrm{P}_{2} \mathrm{X}_{2}$, DSTSTDPKGLAQL; P2X ${ }_{4}$, DYEQGLSGEMNQ. A cysteine residue was added to the $\mathrm{N}$ terminus of the peptide to facilitate coupling to the carrier protein. The peptides were conjugated to BSA and $\mathrm{KLH}$, respectively, and injected into New Zealand White rabbits. Antibodies were purified using the same peptide coupled to SulfoLink resin (Pierce, Rockford, IL). The antibody to GluR2/3 was a generous gift from R. J. Wenthold (Wenthold et al., 1992). Commercial antibodies to P2X $\mathrm{X}_{2}$ and $\mathrm{P}_{2} \mathrm{X}_{4}$ were obtained from Alomone Labs (Jerusalem, Israel).

Polyclonal antibodies to $\mathrm{P} 2 \mathrm{X}_{6}$ were raised using a fusion protein. The cDNA corresponding to the $\mathrm{C}$-terminal domain of rat $\mathrm{P}_{2} \mathrm{X}_{6}$ (aa 355-379) subunit was obtained by PCR from the rat $\mathrm{P}_{2} \mathrm{X}_{6}$ full length cDNA (Soto et al., 1996b) using the following oligonucleotides: forward, 5'-CCGGATCCGATAGAGAGGCCGGTTTCT-3'; reverse, 5'-GGAATAAGCTTTGCACTGTTGGTAGTTGC-3'. The PCR product was cloned in pBlue-script II KS(+) using the BamHI/HindIII sites inserted in the oligonucleotides and sequenced. A PCR fragment containing the correct sequence was subcloned $($ Bam HI/SalI $)$ in frame with glutathione- $S$ transferase (GST) into pGEX-4T vector (Amersham Pharmacia Biotech, Uppsala, Sweden). The same fragment was subcloned (BamHI/HindIII) in frame with thioredoxin (Trx) in the pET32(a)+ vector (Novagen,

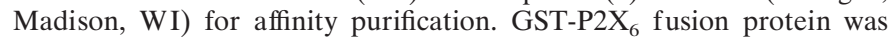
expressed in Escherichia coli (DH5 $\alpha$ strain) and purified from the soluble fraction after bacterial lysis using glutathione-agarose beads (Sigma, St. Louis, MO) as described previously (Smith and Corcoran, 1995). The expected molecular weight of $33 \mathrm{kDa}$ was confirmed by electrophoresis in a $12 \%$ SDS-PAGE. The purified GST-P2X X $_{6}$ usion protein was dialyzed and injected in Chinchilla bastard rabbits for antibody production. The His-tagged Trx-P2X $\mathrm{X}_{6}$ fusion protein was overexpressed in E. coli (BL21 strain) and purified from the soluble fraction using Ni-NTA agarose (Quiagen, Hilden, Germany) following the manufacturer's recommendations. The Trx-P2X $\mathrm{X}_{6}$ fusion protein was covalently coupled to POROS EP 20 (PerSeptive Biosystems, Framingham, MA) and used to affinity purify the antiserum.

Western blot of brain homogenates. Brain homogenates were obtained from postnatal day 5 (P5) Sprague Dawley rats. Ten micrograms of protein for $\mathrm{P} 2 \mathrm{X}_{4}$ and $\mathrm{P}_{2} \mathrm{X}_{6}$ and $35 \mu \mathrm{g}$ for $\mathrm{P} 2 \mathrm{X}_{2}$ were loaded on $12 \%$ SDS-PAGE gels and then transferred to nitrocellulose. Blots were probed with $2 \mu \mathrm{g} / \mathrm{ml}$ of affinity-purified rabbit anti-P2X $\mathrm{X}_{2}, \mathrm{P} 2 \mathrm{X}_{4}$, or $\mathrm{P} 2 \mathrm{X}_{6}$ antibodies. Preadsorption controls were performed by incubating the antibodies to $\mathrm{P} 2 \mathrm{X}_{2}$ and $\mathrm{P} 2 \mathrm{X}_{4}$ with $50 \mu \mathrm{g} / \mathrm{ml}$ of the specific peptide and the antibody to $\mathrm{P} 2 \mathrm{X}_{6}$ with $15 \mu \mathrm{g} / \mathrm{ml}$ of the Trx-P $2 \mathrm{X}_{6}$ fusion protein at $4^{\circ} \mathrm{C}$ for $24 \mathrm{hr}$. Anti-rabbit peroxidase-conjugated secondary antibody was used for visualization with enhanced luminescence (ECL kit, Amersham-Pharmacia Biotech).

Immunostaining of human embryonic kidney-293 cells. Permanent transfection of human embryonic kidney (HEK)-293 cells with a fulllength human $\mathrm{P} 2 \mathrm{X}_{3}$, human $\mathrm{P} 2 \mathrm{X}_{4}$, rat $\mathrm{P} 2 \mathrm{X}_{5}$, or rat $\mathrm{P} 2 \mathrm{X}_{6}$ cDNA cloned in the mammalian expression vector pcDNA3 (Invitrogen, San Diego, CA) was performed using a calcium phosphate precipitation method (Chen and Okoyama, 1987). Independent foci were selected and expanded in the continuous presence of geneticin $(500 \mu \mathrm{g} / \mathrm{ml}$; Sigma $)$. HEK-293 cells transfected with rat $\mathrm{P} 2 \mathrm{X}_{1}$ and $\mathrm{P} 2 \mathrm{X}_{2}$ cDNA were a generous gift from $\mathrm{A}$. Suprenant. All procedures were performed at room temperature. Cultured cells were washed with PBS, fixed with $4 \%$ paraformaldehyde in PBS for 5 min, and blocked with $10 \%$ normal goat serum (NGS) in PBS for $1 \mathrm{hr}$. Permeabilization was achieved with $0.2 \%$ Triton $100-\mathrm{X}$ in PBS. Cells were incubated with a primary antibody $(0.5 \mu \mathrm{g} / \mathrm{ml})$ to $\mathrm{P} 2 \mathrm{X}_{2}, \mathrm{P}_{2} \mathrm{X}_{4}$, or $\mathrm{P}_{2} \mathrm{X}_{6}$ subunits in PBS for $1 \mathrm{hr}$. After washing, cells were incubated with a goat anti-rabbit fluorescein-conjugated secondary antibody (1:500) (Amersham, Arlington Heights, IL) in PBS containing 0.3\% NGS and analyzed with a Zeiss Axiophot microscope.

Light microscopic immunocytochemistry. Six P21 Sprague Dawley rats were anesthetized with a mixture of ketamine $\mathrm{HCl}$ (Ketaset; $100 \mathrm{mg} / \mathrm{ml}$; Fort Dodge Laboratories, Inc.) and xylazine (Rompun; $20 \mathrm{mg} / \mathrm{ml}$; Miles, Elkhart, IN) at $0.1 \mathrm{ml} / 100 \mathrm{gm}$ of body weight. The animals were transcardially perfused with a fixative consisting of $4 \%$ paraformaldehyde in $0.12 \mathrm{M}$ phosphate buffer, $\mathrm{pH}$ 7.2. After perfusion, brains were removed, fixed for an additional hr at $4^{\circ} \mathrm{C}$, rinsed three times in PBS, and stored overnight at $4^{\circ} \mathrm{C}$.

For peroxidase immunocytochemistry, brain coronal and sagittal sections $(40-50 \mu \mathrm{m})$ were cut in cold PBS using a Vibratome (Leica, Vienna, Austria). Slices were incubated for $1 \mathrm{hr}$ in PBS containing 10\% NGS and then with primary antibody to $\mathrm{P}_{2} \mathrm{X}_{2}(1 \mu \mathrm{g} / \mathrm{ml}), \mathrm{P}_{2} \mathrm{X}_{4}(1 \mu \mathrm{g} / \mathrm{ml})$, or $\mathrm{P}_{2} \mathrm{X}_{6}(0.9 \mu \mathrm{g} / \mathrm{ml})$ subunits in PBS overnight at $4^{\circ} \mathrm{C}$ and processed using the avidin-biotin-peroxidase system (Vectastain kit; Vector Laboratories, Burlingame, CA). Antibody binding was visualized using 3'-3diaminobenzidine tetrahydrochloride (DAB) (DAB substrate kit for peroxidase, Vector Laboratories). Controls were performed either by omitting the primary antibody or by preincubating the primary antibody with the corresponding peptide (for $\mathrm{P}_{2} \mathrm{X}_{2}$ and $\mathrm{P} 2 \mathrm{X}_{4} ; 50 \mu \mathrm{g} / \mathrm{ml}$ final concentration) or fusion protein (for $\mathrm{P} 2 \mathrm{X}_{6} ; 15 \mu \mathrm{g} / \mathrm{ml}$ final concentration) at $4^{\circ} \mathrm{C}$ for $24 \mathrm{hr}$ and then by following the procedure described above. Sections were analyzed with a Zeiss Axiophot microscope.

For fluorescence immunocytochemistry, brain sagittal sections $(20-25$ $\mu \mathrm{m}$ ) were incubated for $1 \mathrm{hr}$ in PBS containing 10\% NGS and then with primary antibody $(10 \mu \mathrm{g} / \mathrm{ml})$ to $\mathrm{P} 2 \mathrm{X}_{2}, \mathrm{P}_{2} \mathrm{X}_{4}$, or P2X $\mathrm{X}_{6}$ subunits in PBS at $4^{\circ} \mathrm{C}$ for $24 \mathrm{hr}$. Afterward, sections were incubated with goat anti-rabbit fluorescein-conjugated secondary antibody (1:400; Amersham) in PBS containing $2 \%$ BSA, $0.3 \%$ NGS, and analyzed using a Bio-Rad MRC 1024 confocal microscope.

Freeze substitution. Four P21 Sprague Dawley rats were used for the freeze-substitution procedure. Animals were anesthetized as described above and transcardially perfused with a fixative consisting of $4 \%$ paraformaldehyde and $0.5 \%$ glutaraldehyde in $0.12 \mathrm{M}$ phosphate buffer, $\mathrm{pH}$ 7.2. Brains were then removed and fixed in the same fixative for $90 \mathrm{~min}$ at $4^{\circ} \mathrm{C}$, rinsed in three changes of $0.1 \mathrm{M}$ phosphate buffer, $\mathrm{pH} 7.2$, containing $4 \%$ glucose and stored overnight at $4^{\circ} \mathrm{C}$ in the same buffer. Brain sagittal sections $(300 \mu \mathrm{m})$ were cut in cold $0.1 \mathrm{M}$ phosphate buffer, pH 7.2, containing $4 \%$ glucose, using a Vibratome (Leica). The freeze substitution was performed as described before for glutamate receptors (Rubio and Wenthold, 1997, 1999).

Postembedding immunocytochemistry. Colloidal gold-coupled goat anti-rabbit IgG (5 nm GAR G5 and $10 \mathrm{~nm}$ GAR G10; Amersham) was used to detect rabbit polyclonal antibodies, as described previously ( $\mathrm{Ru}-$ bio and Wenthold, 1997, 1999). All procedures were performed at room temperature. Ultrathin sections $(60-70 \mathrm{~nm})$ on nickel grids (400 mesh) were incubated sequentially in the following solutions: (1) $10 \mathrm{~min}$ in $0.1 \%$ sodium borohydride and $50 \mathrm{~mm}$ glycine in Tris-buffered saline containing $0.1 \%$ Triton X-100 (TBST); (2) 10 min in TBST containing $10 \%$ NGS; (3) $2 \mathrm{hr}$ with primary antibodies to $\mathrm{P}_{2} \mathrm{X}_{2}, \mathrm{P}_{2} \mathrm{X}_{4}(5 \mu \mathrm{g} / \mathrm{ml}), \mathrm{P} 2 \mathrm{X}_{2}$, and $\mathrm{P}^{2} \mathrm{X}_{4}$ (Alomone) $(2 \mu \mathrm{g} / \mathrm{ml})$, and $\mathrm{P}_{2} \mathrm{X}_{6}(9 \mu \mathrm{g} / \mathrm{ml})$ in TBST containing $10 \%$ NGS; (4) $10 \mathrm{~min}$ in TBST; (5) $10 \mathrm{~min}$ in TBST containing $10 \%$ NGS; and (6) $1 \mathrm{hr}$ with colloidal gold-coupled secondary antibody diluted 1:20 in TBST containing 10\% NGS and polyethylene glycol 20,000 (5 $\mathrm{mg} / \mathrm{ml}$ ). Ultrathin sections were counterstained with $1 \%$ uranyl acetate and $0.3 \%$ lead citrate and studied with a Zeiss 100CX II transmission electron microscope at $50 \mathrm{kV}$. Controls were performed either by omitting the primary antibody or by preincubating the primary antibody with the corresponding peptide (for $\mathrm{P} 2 \mathrm{X}_{2}$ and $\mathrm{P} 2 \mathrm{X}_{4} ; 50 \mu \mathrm{g} / \mathrm{ml}$ final concentration) or fusion protein (for $\mathrm{P}_{2} \mathrm{X}_{6} ; 15 \mu \mathrm{g} / \mathrm{ml}$ final concentration) at $4^{\circ} \mathrm{C}$ for $24 \mathrm{hr}$, and then following the procedure described above.

Double immunogold labeling using polyclonal antibodies for $\mathrm{P}_{2} \mathrm{X}_{4}$ and GluR2/3 or $\mathrm{P} 2 \mathrm{X}_{6}$ and GluR2/3 was performed as described previously (Rubio and Wenthold, 1999) using paraformaldehyde vapors between two sequential immunogold-labeling procedures. All double immunogold labeling was repeated after reversing the size of the gold particles. Control experiments were performed by omitting the primary antibody. An additional control consisted of omitting the primary antibody in the sequential immunogold labeling after paraformaldehyde vapors.

Electron micrographs were taken at $30,000 \times$ magnification and scanned at a resolution of 3600 dpi using a Linotype-Hell scanner (Heidelberg, Germany). Image processing was performed with Adobe Photoshop, using only the brightness and contrast commands to enhance the gold particles.

Areas survey. Cerebellar sections were taken from the cerebellar folia III-V to eliminate variations caused by regional differences in cerebellar structure/function and differences in timing of ontogenesis. Posterior folia develop more rapidly than do anterior ones in early postnatal times, and this could affect the level of $\mathrm{P} 2 \mathrm{X}$ receptor expression as has been shown to occur for glutamate receptors (Takayama et al., 1996).

Electron microscopic identification of parallel fiber, climbing fiber (CF), and basket cell (BC) synapses on Purkinje cells was based on 
A
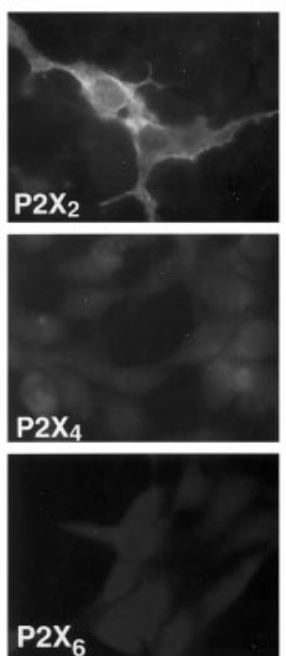

anti-P2X
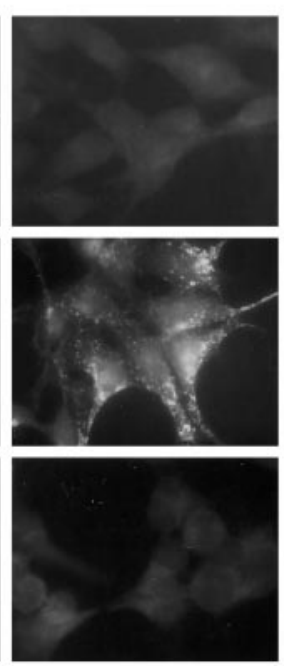

anti-P2X
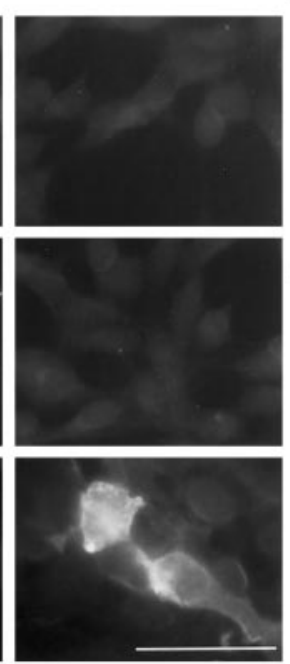

anti-P2X

B

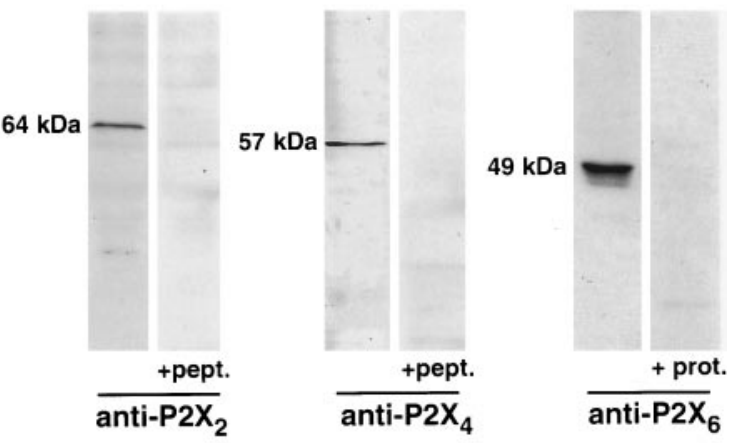

Figure 1. A, Immunofluorescence of HEK-293 cells transfected with $\mathrm{P}_{2} \mathrm{X}_{2}, \mathrm{P}_{2} \mathrm{X}_{4}$, and $\mathrm{P} 2 \mathrm{X}_{6}$ cDNAs using the affinity-purified polyclonal antibodies for $\mathrm{P} 2 \mathrm{X}_{2}, \mathrm{P} 2 \mathrm{X}_{4}$, and $\mathrm{P} 2 \mathrm{X}_{6}$. Only cells transfected with the corresponding cDNAs present immunofluorescence signal. $B$, Immunoblot analysis of SDS-PAGE gels of brain homogenates immunostained with an antibody to $\mathrm{P} 2 \mathrm{X}_{2}, \mathrm{P} 2 \mathrm{X}_{4}$, and $\mathrm{P} 2 \mathrm{X}_{6}$. The polyclonal antibodies recognize only a band migrating at 64 , 57 , and $49 \mathrm{kDa}$ corresponding to $\mathrm{P} 2 \mathrm{X}_{2}, \mathrm{P} 2 \mathrm{X}_{4}$, and $\mathrm{P} 2 \mathrm{X}_{6}$ subunits, respectively. When the immunoblots were performed using preabsorbed antibodies, no bands were observed. Scale bar, $100 \mu \mathrm{m}$.

defined criteria, as reviewed previously (Mugnaini, 1972; Palay and Chan-Palay, 1974; Altman and Bayer, 1997). Parallel fiber-Purkinje cell synapses have small and globular axonal varicosities containing a loose collection of round synaptic vesicles. These varicosities form asymmetrical synapses (Gray Type I) with the spines of spiny branchlets of Purkinje cells dendrites. Climbing fiber varicosities are large and filled with round clear synaptic vesicles, and they form asymmetrical synapses with dendritic spines and larger dendritic shafts of Purkinje cells. They differ from parallel fibers not only in the locus of termination but also in that synaptic vesicles are less regular in their shape, size, and distribution (Altman and Bayer, 1997). Basket cell synaptic terminals contain flattened-pleomorphic synaptic vesicles and make symmetric synaptic contacts (Gray Type II) with the cell bodies of Purkinje cells. Hippocampal sections were taken from the CA1 stratum radiatum. All of the synapses showed the characteristic features of asymmetric synapses (Gray Type I): postsynaptic density, cleft, and round presynaptic vesicles. Synapses that could not be clearly identified by the above criteria were not included in the analysis.

Thin sections were examined from one block from two animals at P21 for $\mathrm{P} 2 \mathrm{X}_{2}, \mathrm{P} 2 \mathrm{X}_{4}$, and $\mathrm{P} 2 \mathrm{X}_{6}$ and for double labeling of $\mathrm{P} 2 \mathrm{X}_{4}$ or $\mathrm{P} 2 \mathrm{X}_{6}$ and GluR2/3. All of the experiments shown have been performed with the antibodies to $\mathrm{P} 2 \mathrm{X}_{2}, \mathrm{P} 2 \mathrm{X}_{4}$, and $\mathrm{P} 2 \mathrm{X}_{6}$ developed in our laboratory; characterization of the antibodies is presented here. As control, qualitative light and electron microscopy were also performed with the $\mathrm{P} 2 \mathrm{X}_{2}$ and $\mathrm{P}_{2} \mathrm{X}_{4}$ antibodies obtained from Alomone, with essentially the same results (data not shown). Qualitative analysis of the distribution of P2X subunits at the electron microscopic level was performed using secondary antibodies coupled to 5 and $10 \mathrm{~nm}$ gold particles. To get the highest possible signal, $5 \mathrm{~nm}$ colloidal gold was used for the semiquantitative analysis (Hayat, 1989).

Quantitative evaluation of $P 2 X$ receptor immunolabeling. Data were collected from cases in which the postsynaptic specializations were well defined. The length of the postsynaptic specializations was measured using NIH Scion Image software, and the number of associated gold particles was counted. Only gold particles $(5 \mathrm{~nm})$ clearly seen at the postsynaptic membranes and within the synaptic cleft were counted. The maximum distance allowed between the postsynaptic specialization and a gold particle was $18 \mathrm{~nm}$, based on the spatial resolution of the immunogold technique (Merighi and Polak, 1993).

To determine axodendritic distribution of gold particles, 20-25 synapses were analyzed. In these synapses, the distance was measured between the center of each gold particle and the outer leaflet of the postsynaptic specialization. The axodendritic axis was divided into $5 \mathrm{~nm}$ bins, and each gold particle was assigned to one bin. All gold particles located $100 \mathrm{~nm}$ from the outer leaflet of the postsynaptic specialization to the presynaptic and postsynaptic sides were included in the analysis.

To define tangential distribution of labeling along the postsynaptic specialization, the distance of each gold particle from the center of the synaptic profile was measured and normalized. The radial length was divided into five equal bins, and each gold particle was assigned to a bin. An additional bin of $20 \%$ (i.e., 100-120\%) was included to sample the perisynaptic region (Matsubara et al., 1996; Petralia et al., 1998). The tangential distribution was measured independently in two animals, and both of them showed the same distribution along the postsynaptic specialization.

The relative density of $\mathrm{P} 2 \mathrm{X}$ receptor imunolabeling in cerebellum and hippocampus was determined in a sample of 133 and 124 presynaptic terminals and 110 and 83 glial profiles, respectively. The sample included $>20$ areas for each of the profiles and for each of the antibodies analyzed. All Bergmann glia (cerebellum) and astrocyte (hippocampus) profiles were identified following described criteria (Palay and Chan-Palay, 1974; Peters et al., 1991; Ventura and Harris, 1999). Briefly, astrocytic processes were identified by their irregular, stellate shape and by the presence of glycogen granules and bundles of intermediate filaments in a relatively clear cytoplasm. Only identified glial profiles located at $1 \mu \mathrm{m}^{2}$ around the synapse were measured. After counting the gold particles for each presynaptic or glial profile, the perimeter of each segment was measured using NIH Scion Image software. Once the number of gold particles and the area of each profile were known, the average density of gold particles was computed automatically for each type of dendritic or presynaptic profile.

\section{RESULTS}

\section{Specificity of antibodies to $\mathrm{P}_{2} \mathrm{X}_{2}, \mathrm{P}_{2} \mathrm{X}_{4}$, and $\mathbf{P}_{2} \mathrm{X}_{6}$ subunits}

We have generated rabbit polyclonal antibodies against C-terminal sequences of $\mathrm{rP}_{2} \mathrm{X}_{2}, \mathrm{rP} 2 \mathrm{X}_{4}$, and $\mathrm{rP}_{2} \mathrm{X}_{6}$ subunits, which show little intersubunit homology (Soto et al., 1997). However, to demonstrate the subunit specificity of the corresponding antibody, we used immunofluorescence labeling of cells expressing $\mathrm{rP} 2 \mathrm{X}_{2}, \mathrm{hP} 2 \mathrm{X}_{4}$, and $\mathrm{rP} 2 \mathrm{X}_{6}$ subunits (Fig. $1 A$ ). Immunofluorescence signals were detected only with the antibody raised against the specific subtype. Affinity-purified antibody to rat $\mathrm{P} 2 \mathrm{X}_{4}$ subunit showed cross-reactivity with the human homolog, something that could be expected because of the high percentage of 
A
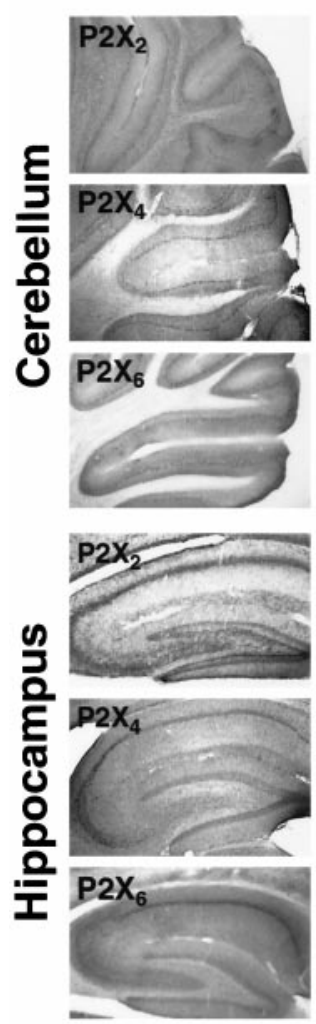
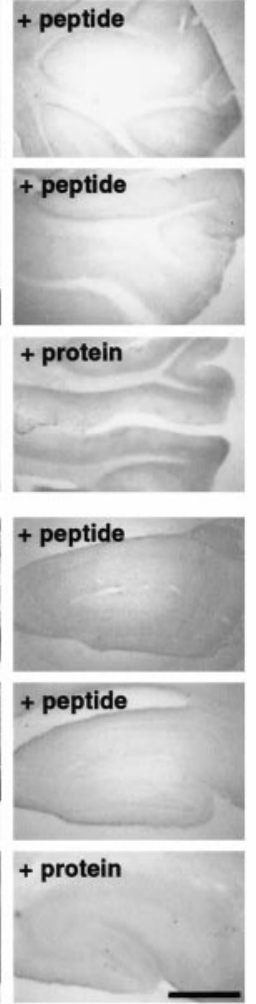

B
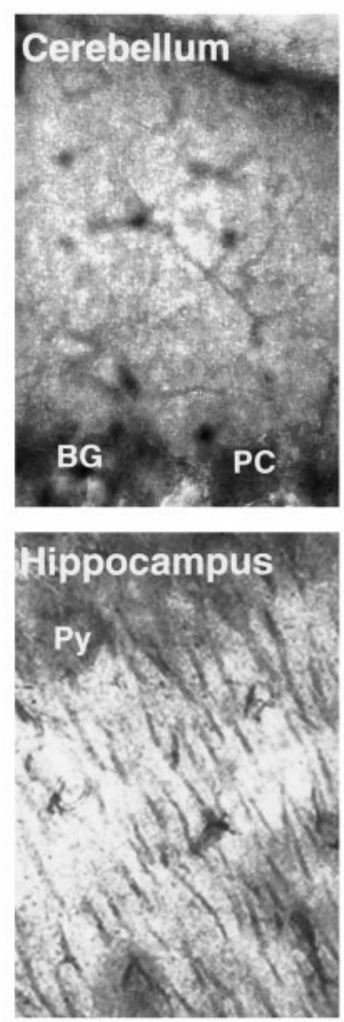

$\mathrm{P} 2 \mathrm{X}_{2}$
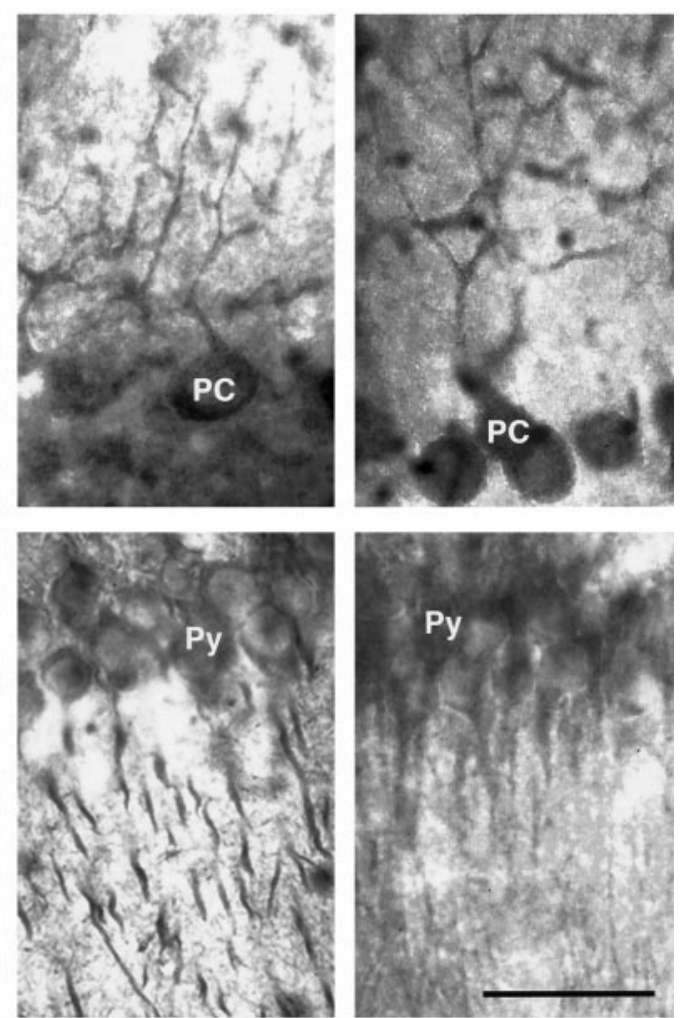

${\mathrm{P} 2 \mathrm{X}_{4}}$

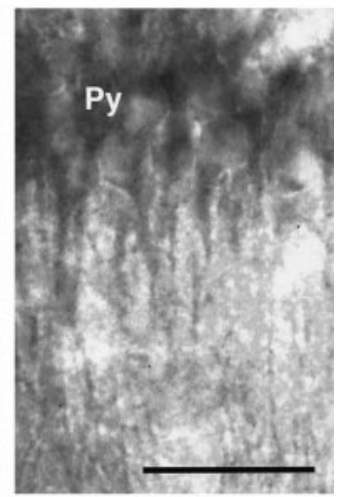

${\mathrm{P} 2 \mathrm{X}_{6}}$

Figure 2. Light-microscopic micrographs showing the immunohistochemical reactions for $\mathrm{P}_{2} \mathrm{X}_{2}, \mathrm{P}_{2} \mathrm{X}_{4}$, and $\mathrm{P} 2 \mathrm{X}_{6}$ in cerebellum and hippocampus. $A$, Low-magnification views of cerebellum and hippocampus plus preadsorption controls. $B$, High-magnification views of Purkinje cells $(P C)$ in cerebellum and CA1 pyramidal cells $(P y)$ in hippocampus showing immunohistochemical reactions for $\mathrm{P}_{2} \mathrm{X}_{2}, \mathrm{P}_{2} \mathrm{X}_{4}$, and $\mathrm{P} 2 \mathrm{X}_{6}$. Both cell types present immunohistochemical reactions extending from the cell body to the most distal dendrites. A punctate pattern resembling dendritic spines labeling is observed. $B G$, Bergmann glia. Scale bars: $A, 2 \mathrm{~mm} ; B, 50 \mu \mathrm{m}$.

amino acid identity between the rat and the human sequence (Garcia-Guzman et al., 1997). For cells transfected with $\mathrm{P} 2 \mathrm{X}_{1}$, $\mathrm{P} 2 \mathrm{X}_{3}$, and $\mathrm{P} 2 \mathrm{X}_{5}$ subunits, no immunofluorescence labeling was visible (data not shown).

To demonstrate the specificity of the generated antibodies in native tissue, Western blots of crude membranes isolated from rat brain were performed. Single bands of 64, 57, and $49 \mathrm{kDa}$ were detected with affinity-purified antibodies to $\mathrm{P} 2 \mathrm{X}_{2}, \mathrm{P} 2 \mathrm{X}_{4}$, and $\mathrm{P}_{2} \mathrm{X}_{6}$ subunits, respectively (Fig. $1 B$ ). No bands could be detected when the primary antibody used for Western blot was preincubated with the corresponding peptide or fusion protein, indicating the specificity of the antibody for the epitope (Fig. 1B). The molecular weight of $57 \mathrm{kDa}$ detected for $\mathrm{P}_{2} \mathrm{X}_{4}$ subunits is in good agreement with the value previously reported by Lê and coworkers (Lê et al., 1998b), and a molecular weight of $65 \mathrm{kDa}$ has been described for $\mathrm{P}_{2} \mathrm{X}_{2}$ subunits expressed in Xenopus oocytes (Newbolt et al., 1998). The molecular weights obtained for the three subunits were always higher than those predicted from the amino acidic sequence $\left(53,44\right.$, and $42 \mathrm{kDa}$ for $\mathrm{P} 2 \mathrm{X}_{2}, \mathrm{P} 2 \mathrm{X}_{4}$, and $\mathrm{P} 2 \mathrm{X}_{6}$, respectively). This might be explained by $\mathrm{N}$-glycosylation occurring at consensus sequences in the extracellular loop (Brake et al., 1994; Collo et al., 1996). A different degree of N-glycosylation could account for the smear observed under the band for $\mathrm{P}_{2} \mathrm{X}_{6}$ in Figure $1 B$. Modification of $\mathrm{P} 2 \mathrm{X}$ receptors by $\mathrm{N}$-glycosylation has been demonstrated experimentally for $\mathrm{P}_{2} \mathrm{X}_{1}$ (Valera et al., 1994)

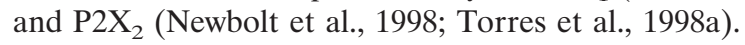

\section{Light microscopic immunocytochemistry of $\mathrm{P}_{2} \mathrm{X}_{2}$, $\mathrm{P}^{2} \mathrm{X}_{4}$, and $\mathrm{P}_{2} \mathrm{X}_{6}$ in cerebellum and hippocampus}

At the level of light microscopy (Figs. 2, 3), all three subunits of $\mathrm{P} 2 \mathrm{X}$ receptors analyzed $\left(\mathrm{P} 2 \mathrm{X}_{2}, \mathrm{P} 2 \mathrm{X}_{4}\right.$, and $\left.\mathrm{P} 2 \mathrm{X}_{6}\right)$ were detected in cerebellum and hippocampus. We obtained the same patterns of expression using the antibodies developed in our laboratory and the commercial antibodies for $\mathrm{P}_{2} \mathrm{X}_{2}$ and $\mathrm{P} 2 \mathrm{X}_{4}$.

In cerebellum, Purkinje cells were the only cell type showing immunoreactivity for the three subunits, with different intensities: from weak for $\mathrm{P}_{2} \mathrm{X}_{2}$ to strong for $\mathrm{P} 2 \mathrm{X}_{4}$ and $\mathrm{P} 2 \mathrm{X}_{6}$. Labeling extended from the cell body to dendrites (Figs. 2B, 3). Dendritic labeling was strong for $\mathrm{P}_{2} \mathrm{X}_{4}$ and $\mathrm{P} 2 \mathrm{X}_{6}$ and weak for $\mathrm{P} 2 \mathrm{X}_{2}$. Also, a punctate pattern resembling dendritic spine labeling was detected for $\mathrm{P} 2 \mathrm{X}_{2}, \mathrm{P} 2 \mathrm{X}_{4}$, and $\mathrm{P} 2 \mathrm{X}_{6}$ (Fig. 3). Antibodies for $\mathrm{P} 2 \mathrm{X}_{4}$ also labeled basket and stellate cells in the molecular layer (data not shown) and strongly labeled granule cells in the granular layer(Figs. 2B, 3). Additionally, $\mathrm{P} 2 \mathrm{X}_{2}$ immunoreactivity was detected in basket cells, in Bergmann glia, and in synaptic boutons in the granular cell layer. Immunostaining for $\mathrm{P}_{2} \mathrm{X}_{6}$ was only observed on Purkinje cells. In the hippocampus, pyramidal cells in the CA1 and CA3 region and granule cells in the dentate gyrus were stained with antibodies for $\mathrm{P} 2 \mathrm{X}_{2}$ and $\mathrm{P} 2 \mathrm{X}_{4}$. Immunohistochemical reaction for the $\mathrm{P}_{2} \mathrm{X}_{6}$ antibody was predominantly detected in CA1 and to a lesser extent in CA3 pyramidal cells. In CA1 pyramidal cells, labeling for the three subunits extended 

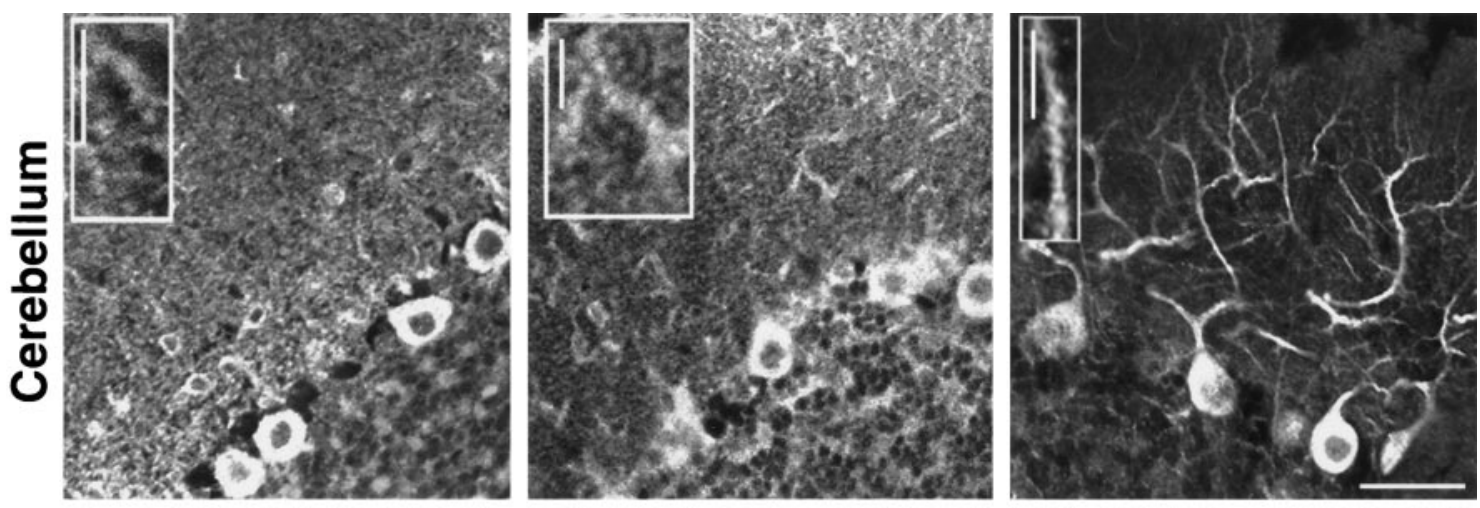

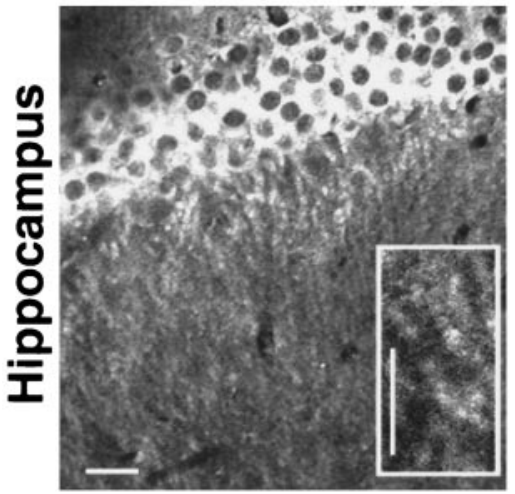

$\mathrm{P}^{2} \mathrm{X}_{2}$

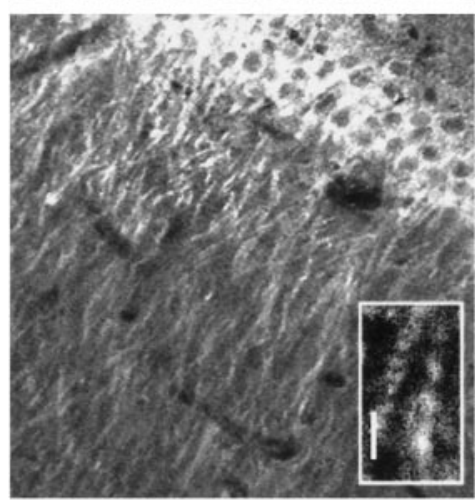

$\mathrm{P}^{2} \mathrm{X}_{4}$

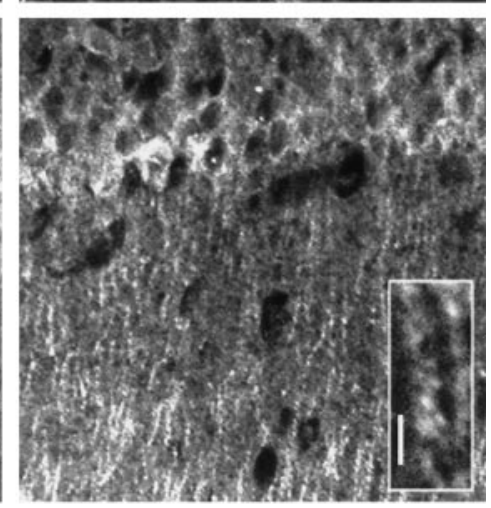

$\mathrm{P}^{2} \mathrm{X}_{6}$

Figure 3. Confocal images showing immunofluorescence for $\mathrm{P} 2 \mathrm{X}_{2}, \mathrm{P} 2 \mathrm{X}_{4}$, and $\mathrm{P} 2 \mathrm{X}_{6}$ in cerebellum and hippocampus. Immunofluorescence signal is observed in cell bodies, dendrites, and dendritic spines of cerebellar Purkinje cells and hippocampal CA1 pyramidal neurons. Insets show a magnification of apical dendrites. Scale bars: $100 \mu \mathrm{m}$; insets, $25 \mu \mathrm{m}$.

from the cell body to the most distal dendrites, including dendritic spines in the stratum radiatum (Figs. $2 B$, 3). Immunohistochemical reaction was not observed in synaptic boutons with any of the antibodies for the P2X subunits analyzed. Both omission of primary antiserum (data not shown) and preadsorption of purified $\mathrm{P} 2 \mathrm{X}_{2}, \mathrm{P} 2 \mathrm{X}_{4}$, and $\mathrm{P} 2 \mathrm{X}_{6}$ antibodies with the corresponding peptide or fusion protein (Fig. $2 A$ ) resulted in the lack of DAB immunoreaction, confirming the specificity of the assay.

\section{Immunogold labeling for $\mathrm{P}_{2} \mathrm{X}_{2}, \mathrm{P}_{2} \mathrm{X}_{4}$, and $\mathrm{P}^{2} \mathrm{X}_{6}$ at synapses of parallel fibers onto Purkinje cells in cerebellum}

The distribution of $\mathrm{P} 2 \mathrm{X}_{2}, \mathrm{P} 2 \mathrm{X}_{4}$, and $\mathrm{P} 2 \mathrm{X}_{6}$ subunits in cerebellum was analyzed in 306 synapses. The sample included previously described excitatory synapses of PFs $(n=159)$ and CFs $(n=72)$ and inhibitory synapses of BCs $(n=80)$ on cell bodies of Purkinje cells. Only $\mathrm{PF}$ synapses showed immunogold labeling for $\mathrm{P} 2 \mathrm{X}_{2}$, $\mathrm{P} 2 \mathrm{X}_{4}$, and $\mathrm{P} 2 \mathrm{X}_{6}$, with no labeling at $\mathrm{CF}$ and $\mathrm{BC}$ synapses.

Examples of postembedding immunogold labeling of PF/Purkinje cell synapses are shown in Figure 4. All 159 PF synapses analyzed (Table 1) were localized in the molecular layer and enwrapped by processes of Bergmann glia. In our sample of PF synapses analyzed, we found that $55 \%(n=29)$, $57 \%(n=30)$, and $68 \%(n=38)$ were immunogold-labeled for $\mathrm{P} 2 \mathrm{X}_{2}, \mathrm{P} 2 \mathrm{X}_{4}$, and $\mathrm{P} 2 \mathrm{X}_{6}$, respectively. Qualitatively, all antibodies used gave a similar pattern of immunogold labeling on PF/Purkinje cells (Fig. 4). Gold particles were mainly present at the postsynaptic specializations (Fig. 4) and extended at lower levels perisynaptically and intracellularly with relation to endoplasmic reticulum membranes (Fig. 5). The location of gold particles was quantitatively assessed by analyzing their axodendritic distribution in 20 synapses (per antibody). The distribution profile of $\mathrm{P}_{2} \mathrm{X}_{2}, \mathrm{P} 2 \mathrm{X}_{4}$, and $\mathrm{P} 2 \mathrm{X}_{6}$ gold particles shows a preferentially postsynaptic localization of these receptor subunits (Fig. 6) (peaks extend from $\sim 5$ to $35 \mathrm{~nm}$ inside the postsynaptic specialization). The density of gold particles in relation to the length of the postsynaptic specialization was also analyzed, and the results are shown in Table 1.

The analysis of the tangential distribution of gold particles (66 particles in 21 synapses for $\mathrm{P}_{2} \mathrm{X}_{2}, 98$ particles in 28 synapses for $\mathrm{P}_{2} \mathrm{X}_{4}$, and 129 particles in 33 synapses for $\mathrm{P} 2 \mathrm{X}_{6}$ ) showed that the labeling was relatively low in the central part of the synapse and dramatically increased in the peripheral portions (Fig. 6).

We also analyzed the density of gold particles for $\mathrm{P} 2 \mathrm{X}_{2}$, $\mathrm{P} 2 \mathrm{X}_{4}$, and $\mathrm{P} 2 \mathrm{X}_{6}$ in presynaptic terminals of cerebellar $\mathrm{PF}$ synapses $(n=133)$ and found very low levels [particles per squared micrometer $\left(\mu \mathrm{m}^{2}\right) \pm \mathrm{SEM}=1.4 \pm 0.5$ for $\mathrm{P} 2 \mathrm{X}_{2}, 0.6 \pm$ 0.4 for $\mathrm{P}_{2} \mathrm{X}_{4}$, and $0.9 \pm 0.3$ for $\left.\mathrm{P}_{2} \mathrm{X}_{6}\right]$.

\section{Immunogold labeling for $\mathrm{P}_{2} \mathrm{X}_{2}, \mathrm{P}_{2} \mathrm{X}_{4}$, and $\mathrm{P} 2 \mathrm{X}_{6}$ at synapses of Schaffer collaterals onto CA1 pyramidal cells in hippocampus}

Examples of postembedding immunogold labeling of excitatory synapses on pyramidal cells in CA1 stratum radiatum are shown in Figure 7. Excitatory synapses $(n=184)$ were used to analyzed the distribution of $\mathrm{P}_{2} \mathrm{X}_{2}(n=55), \mathrm{P}_{2} \mathrm{X}_{4}(n=63)$, and $\mathrm{P}_{2} \mathrm{X}_{6}(n=66)$ subunits in this region. Of these synapses, 25 (45\%), 29 (46\%), and $37(56 \%)$ presented immunogold labeling for $\mathrm{P} 2 \mathrm{X}_{2}, \mathrm{P} 2 \mathrm{X}_{4}$, and $\mathrm{P} 2 \mathrm{X}_{6}$, respectively. Qualitatively, all antibodies gave a similar pattern of immunogold labeling on dendrites and spines of the stratum radiatum (Fig. 7). Gold particles were mainly present at the postsynaptic specializations and extended at lower levels perisynaptically and intra- 


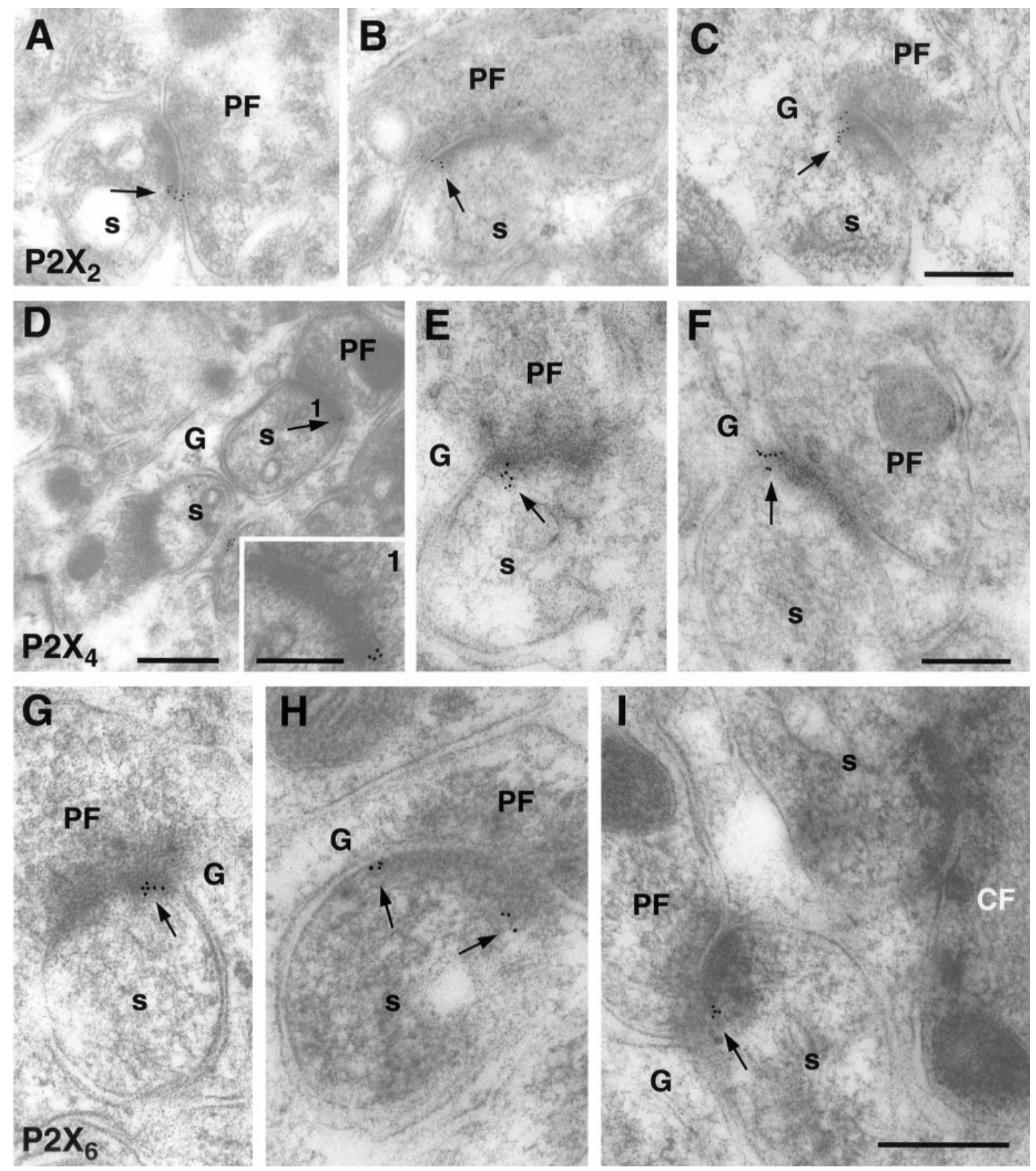

Figure 4. Electron micrographs showing postembedding immunogold labeling for $\mathrm{P}_{2} \mathrm{X}_{2}(A-C), \mathrm{P}_{2} \mathrm{X}_{4}(D-F)$, and $\mathrm{P} 2 \mathrm{X}_{6}(G-I)$ at postsynaptic specializations of parallel fibers $(P F)$ on Purkinje cells in the molecular layer of cerebellum. Gold particles (5 nm; arrows) are observed at the peripheral portions of the postsynaptic specialization. I, A PF and a climbing fiber synapse $(C F)$ making synaptic contact with dendritic spines of Purkinje cells. Immunogold labeling is observed only at the postsynaptic specialization of PF. $G$, Bergmann glia; s, spine. Scale bars: $0.250 \mu \mathrm{m}$; inset, $0.125 \mu \mathrm{m}$.

cellularly with relation to endoplasmic reticulum membranes (Fig. 6). The location of gold particles was quantitatively assessed by analyzing their axodendritic distribution in 25 synapses (per antibody). The distribution profile of $\mathrm{P} 2 \mathrm{X}_{2}$, $\mathrm{P} 2 \mathrm{X}_{4}$, and $\mathrm{P} 2 \mathrm{X}_{6}$ gold particles shows a preferentially postsynaptic localization of these receptor subunits (Fig. 8) (peaks

Table 1. Summary of the postembedding immunoreactivity for $\mathrm{P} 2 \mathrm{X}_{2}, \mathrm{P}_{\mathrm{X}}$, and $\mathrm{P} 2 \mathrm{X}_{6}$ in $\mathrm{PF} / \mathrm{PC}$ of the cerebellum

\begin{tabular}{|c|c|c|c|c|}
\hline Receptors & Number of PSDs & Average length of PSD $(\mu \mathrm{m})$ & $\begin{array}{l}\text { Average number of gold particles } \\
\text { per PSD (range) }\end{array}$ & $\begin{array}{l}\text { Number of gold particles per } \\
\text { micrometers of PSD } \pm \text { SEM }\end{array}$ \\
\hline $\mathrm{P} 2 \mathrm{X}_{2}$ & 53 & $0.26 \pm 0.01$ & $1.9(0-7)$ & $8.4 \pm 1.3$ \\
\hline $\mathrm{P} 2 \mathrm{X}_{4}$ & 53 & $0.26 \pm 0.01$ & $2.1(0-8)$ & $9.3 \pm 1.7$ \\
\hline $\mathrm{P} 2 \mathrm{X}_{6}$ & 53 & $0.23 \pm 0.01$ & $2.7(0-8)$ & $12.4 \pm 1.6$ \\
\hline
\end{tabular}

PSD, Postsynaptic specialization. 


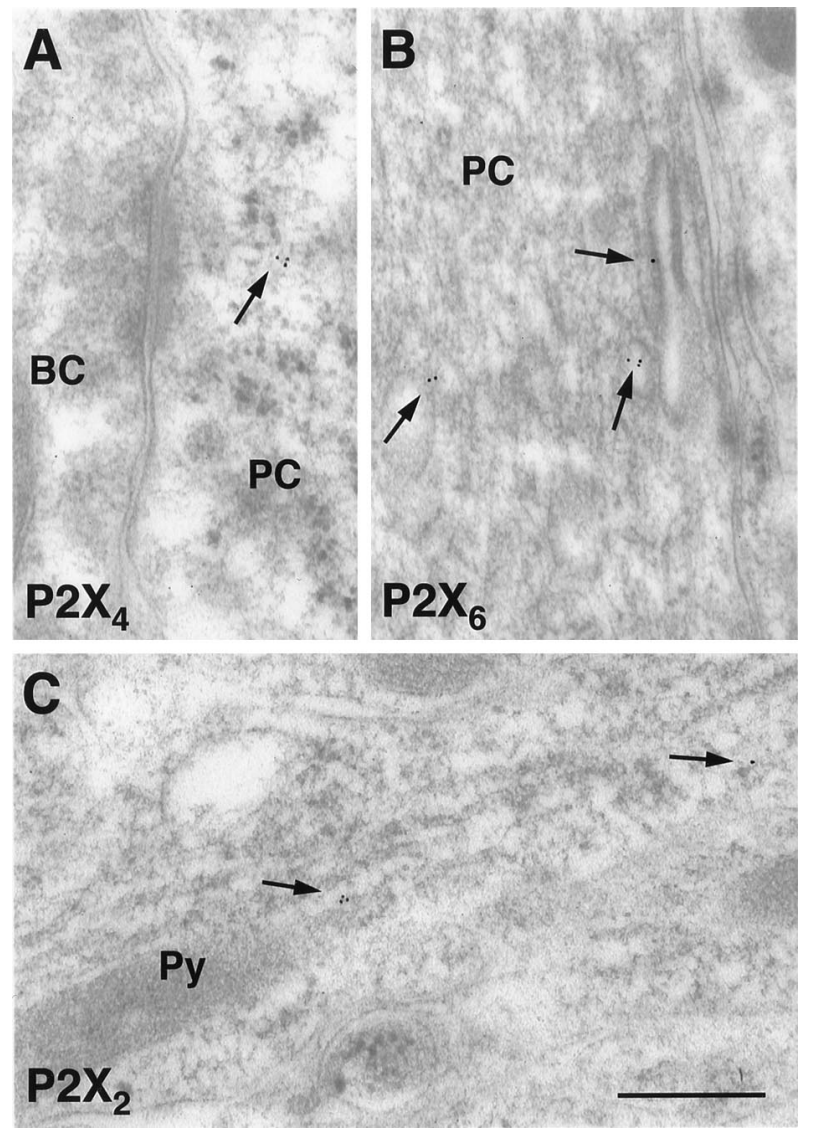

Figure 5. Electron micrographs showing the intracellular immunogold labeling for $\mathrm{P}_{2} \mathrm{X}_{2}(C), \mathrm{P}_{2} \mathrm{X}_{4}(A)$, and $\mathrm{P}_{2} \mathrm{X}_{6}(B)$ in Purkinje cells of cerebellum $(A, B)$ and hippocampal CA1 pyramidal cells $(C)$. Gold particles (arrows) are observed intracellularly in relation to endoplasmic reticulum membranes. $A$, A basket cell $(B C)$ /Purkinje cell $(P C)$ synapse lacking gold labeling at the postsynaptic specialization. Py, Pyramidal cell. Scale bar, $0.250 \mu \mathrm{m}$.

extend from $\sim 5$ to $40 \mathrm{~nm}$ inside the postsynaptic specialization). The density of gold particles in relation to the length of the postsynaptic specialization was also analyzed, and the results are shown in Table 2 . In our analysis of $\mathrm{P} 2 \mathrm{X}$ receptor subunit distribution in CA1, no variation in the number of gold particles between the populations of big and small spines (Takumy et al., 1999) was observed.

The analysis of the tangential distribution of gold particles (76 particles in 24 synapses for $\mathrm{P} 2 \mathrm{X}_{2}, 80$ particles in 25 synapses for $\mathrm{P}_{2} \mathrm{X}_{4}$, and 125 particles in 35 synapses for $\mathrm{P} 2 \mathrm{X}_{6}$ ) showed that the labeling was relatively low in the central part of the synapse and dramatically increased in the peripheral portion (Fig. 8). This tangential distribution is similar to the one at the postsynaptic specialization of the PF/Purkinje cell synapses (see above).

The density of gold particles obtained for $\mathrm{P} 2 \mathrm{X}_{2}, \mathrm{P} 2 \mathrm{X}_{4}$, and $\mathrm{P}_{2} \mathrm{X}_{6}$ in presynaptic terminals of Schaffer collaterals $(n=144)$ in hippocampus was very low [particles per squared micrometer $\left(\mu \mathrm{m}^{2}\right) \pm \mathrm{SEM}=0.6 \pm 0.2$ for $\mathrm{P} 2 \mathrm{X}_{2}, 0.2 \pm 0.1$ for $\mathrm{P} 2 \mathrm{X}_{4}$, and $0.6 \pm$ 0.2 for $\mathrm{P} 2 \mathrm{X}_{6}$ ].

It has been shown that in CA1 stratum radiatum $\sim 58 \%$ of the synapses have astrocytic processes at their perimeters (Ventura and Harris, 1999). Because of the predominance of $\mathrm{P} 2 \mathrm{X}$ receptor immunogold labeling at the outer portions of the postsynaptic specialization, we wanted to know from our sample of synapses analyzed $(n=184)$ in this brain region how many had astrocytic
Axodendritic

Tangential
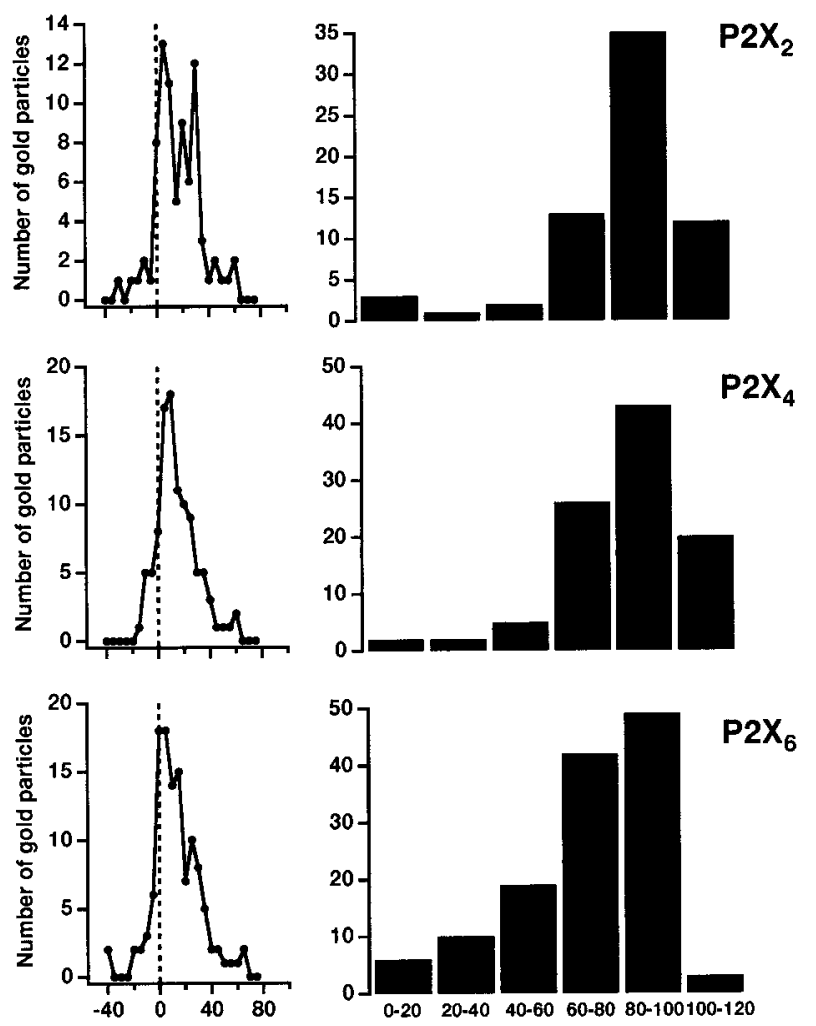

Axodendritic position (nm)

Distance from center of profile $(\%)$

Figure 6. Axodendritic (left) and tangential (right) distribution of gold particles representing $\mathrm{P} 2 \mathrm{X}_{2}, \mathrm{P}_{2} \mathrm{X}_{4}$, and $\mathrm{P} 2 \mathrm{X}_{6}$ at PF-Purkinje cell synapses in cerebellum. The axodendritic distribution of gold particles was analyzed in 20-25 synapses. The distance was measured between the center of each gold particle and the outer leaflet of the postsynaptic specialization. Labeling density of particles at each distance is plotted. $\mathrm{P} 2 \mathrm{X}$ receptor immunogold distribution peaks at $5-40 \mathrm{~nm}$ postsynaptic to the plasma membrane. For the tangential distribution, each bin in the histogram represents one-fifth of the radial length of the postsynaptic specialization, with zero defined as the center. The data were pooled from $21\left(\mathrm{P} 2 \mathrm{X}_{2}\right), 28\left(\mathrm{P} 2 \mathrm{X}_{4}\right)$, and $33\left(\mathrm{P} 2 \mathrm{X}_{6}\right)$ synapses. Only synaptic profiles of at least $200 \mathrm{~nm}$ diameter were included in the analysis. Immunolabeling for all subunits occurs along the mediolateral extent of the postsynaptic specialization, with a dramatic increase at the peripheral portion. Gold particles were also present at the perisynaptic region of the postsynaptic specialization.

profiles at their perimeters and of these how many were immunogold-labeled for P2X subunits. We found that 98 synapses $(53 \%)$ had well defined astrocytic profiles at their perimeters, from which $62(63 \%)$ presented gold particles for P2X receptors at the postsynaptic specialization.

Immunogold labeling of $\mathrm{P}_{2} \mathrm{X}_{2}, \mathrm{P} 2 \mathrm{X}_{4}$, and $\mathrm{P} 2 \mathrm{X}_{6}$ subunits in glia processes in cerebellum and hippocampus

Light-microscopy and pre-embedding immunocytochemistry studies have reported the presence of several P2X receptor subunits on glial cells (Loesch and Burnstock, 1998; Kanjhan et al., 1999; this study). To know the levels of expression for $\mathrm{P} 2 \mathrm{X}_{2}$, $\mathrm{P} 2 \mathrm{X}_{4}$, and $\mathrm{P} 2 \mathrm{X}_{6}$ subunits in glial cells, we analyzed the relative density of gold particles in processes of cerebellar Bergmann glia and CA1 hippocampal astrocytes $1 \mu \mathrm{m}^{2}$ around the synapse. Relatively low levels of gold particles for the three subunits both 

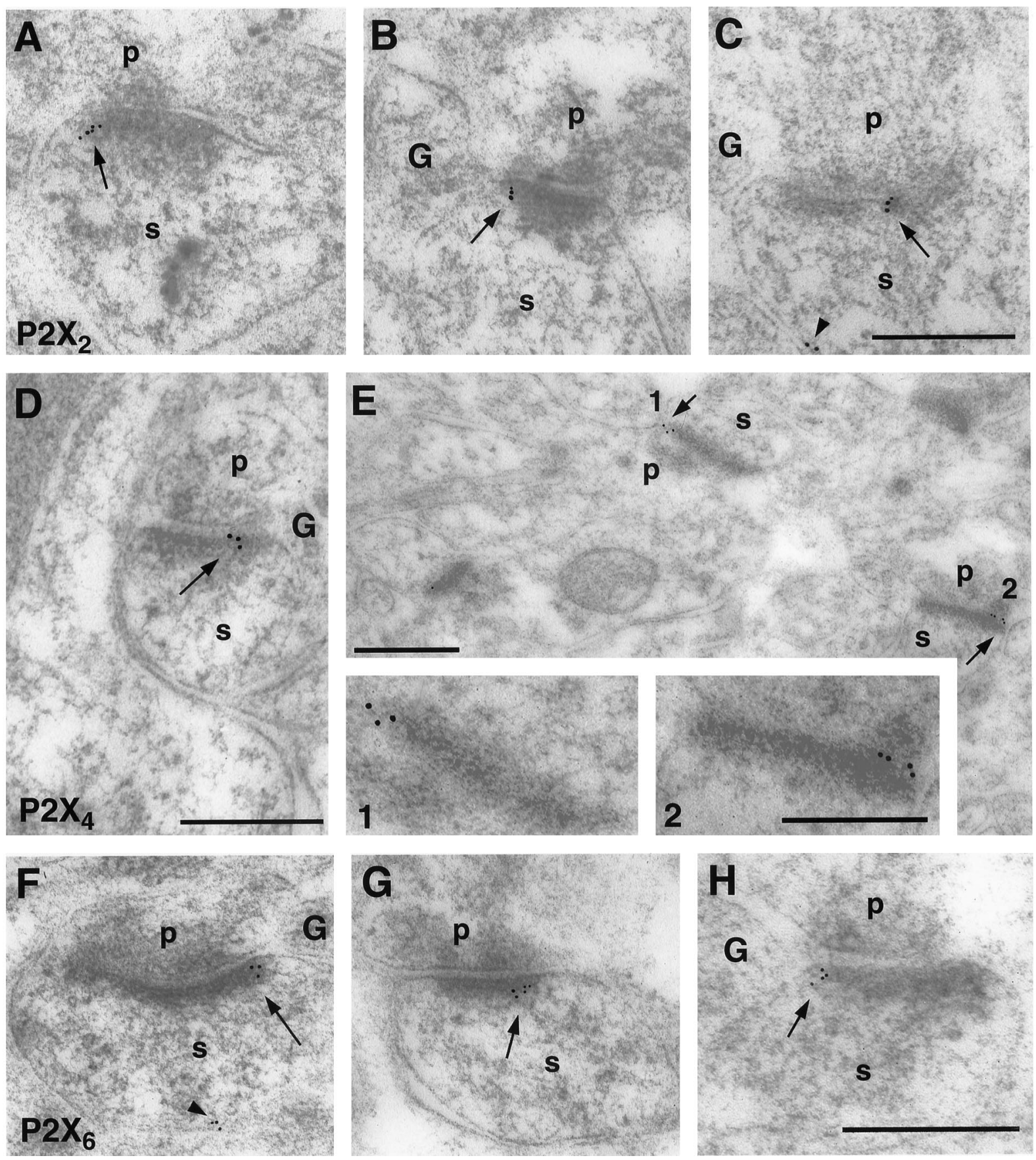

Figure 7. Electron micrographs showing postembedding immunogold labeling for $\mathrm{P}_{2} \mathrm{X}_{2}(A-C), \mathrm{P}_{2} \mathrm{X}_{4}(D-E)$, and $\mathrm{P} 2 \mathrm{X}_{6}(F-H)$ in $C A 1$ stratum radiatum of the hippocampus. Gold particles $(5 \mathrm{~nm}$; arrows) are observed at the peripheral portions of the postsynaptic specialization. In two spines $(C, F)$, immunogold labeling was also observed at the plasma membrane (arrowhead). $C$, A putative perforated synapse; gold particles were located at the periphery of one of the two postsynaptic specializations observed. $G$, Astrocytes; $p$, presynaptic; $s$, spine. Scale bars: $0.250 \mu \mathrm{m}$; inset, $0.125 \mu \mathrm{m}$.

in the Bergmann glia [gold particles per squared micrometer $\left(\mu \mathrm{m}^{2}\right) \pm \mathrm{SEM}=1.3 \pm 0.3$ for $\mathrm{P}_{2} \mathrm{X}_{2}, 1.1 \pm 0.4$ for $\mathrm{P}_{2} \mathrm{X}_{4}$ and $1.4 \pm$ 0.7 for $\mathrm{P}_{2} \mathrm{X}_{6}$ ] and in the CA1 astrocytes [gold particles per squared micrometer $\left(\mu \mathrm{m}^{2}\right) \pm \mathrm{SEM}=0.2 \pm 0.2 \mathrm{P} 2 \mathrm{X}_{2}, 0.2 \pm 0.1$ $\mathrm{P}_{2} \mathrm{X}_{4}$, and $0.7 \pm 0.5 \mathrm{P}_{2} \mathrm{X}_{6}$ ] were obtained.

\section{Colocalization of P2X receptors with AMPA receptors at excitatory postsynaptic membranes in cerebellum and hippocampus}

In addition to the well described ultrastructural characteristics used to identify excitatory synapses in the CNS, we verified that
P2X receptor subunits were localized at glutamatergic synapses in cerebellum and hippocampus by double postembedding immunocytochemistry. We combined antibodies against $\mathrm{P} 2 \mathrm{X}_{4}, \mathrm{P} 2 \mathrm{X}_{6}$ (Fig. 9), or $\mathrm{P}_{2} \mathrm{X}_{2}$ (data not shown) with an antibody against the GluR2/3 subunits of AMPA receptors using sequential immunogold labeling. Postsynaptic specializations of PF synapses in cerebellum and Schaffer collateral synapses in hippocampus presented gold particles for both P2X and AMPA receptors. From the 25 synapses analyzed for each antibody in both cerebellum and hippocampus, approximately half presented gold particles for 
Axodendritic
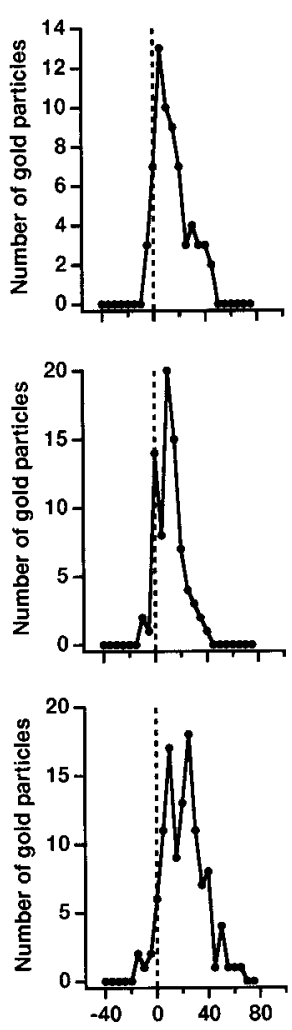

Axodendritic position ( $\mathrm{nm})$
Tangential
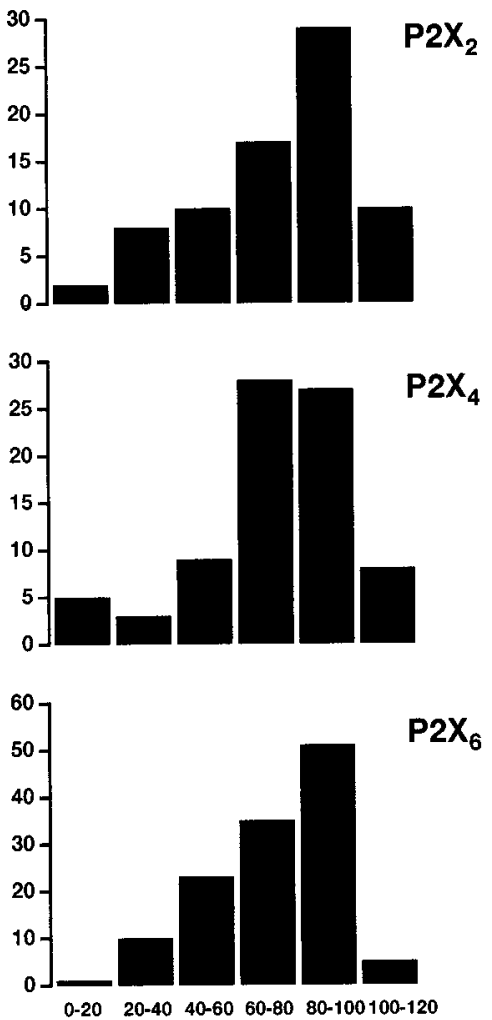

Distance from center of profile $(\%)$

Figure 8. Axodendritic (left) and tangential (right) distribution of gold particles representing $\mathrm{P} 2 \mathrm{X}_{2}, \mathrm{P} 2 \mathrm{X}_{4}$, and $\mathrm{P} 2 \mathrm{X}_{6}$ at excitatory synapses in the CA1 stratum radiatum of the hippocampus. The axodendritic distribution of gold particles was analyzed in 20-25 synapses. The distance was measured between the center of each gold particle and the outer leaflet of the postsynaptic specialization. Labeling density of particles at each distance is plotted. $\mathrm{P} 2 \mathrm{X}$ receptor immunogold distribution peaks at 5-40 $\mathrm{nm}$ postsynaptic to the plasma membrane. For the tangential distribution, each bin in the histogram represents one-fifth of the radial length of the postsynaptic specialization, with zero defined as the center. The data were pooled from $24\left(\mathrm{P} 2 \mathrm{X}_{2}\right), 25\left(\mathrm{P}_{2} \mathrm{X}_{4}\right)$, and $35\left(\mathrm{P} 2 \mathrm{X}_{6}\right)$ synapses. Only synaptic profiles with at least $200 \mathrm{~nm}$ of diameter were included in the analysis. Immunolabeling for all subunits occurs along the mediolateral extent of the postsynaptic specialization, with a dramatic increase at the peripheral portion. Gold particles were also present at the perisynaptic region of the postsynaptic specialization.

both P2X and AMPA subunits. Synapses that were immunogoldlabeled for only one type of receptor $(n=5-7)$ or without gold particles $(n=5-7)$ were also observed. However, this must be considered only an approximation because of the limitations of the sequential immunogold-labeling technique (Rubio and Wenthold, 1999; Racca et al., 2000; Sassoè-Pognetto and Ottersen, 2000).

Cerebellum

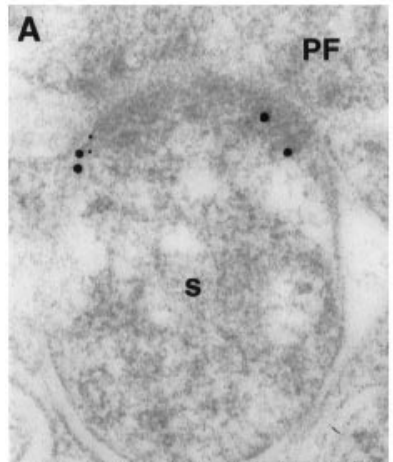

$\mathrm{P}^{2} \mathrm{X}_{4}(5 \mathrm{~nm})+$ GluR2/3 $(10 \mathrm{~nm})$

C

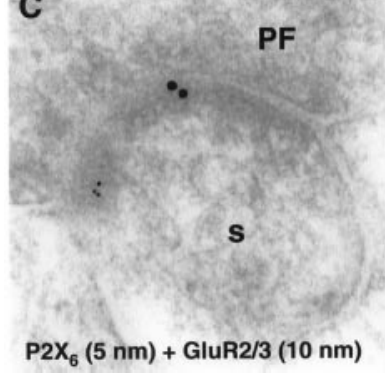

Hippocampus
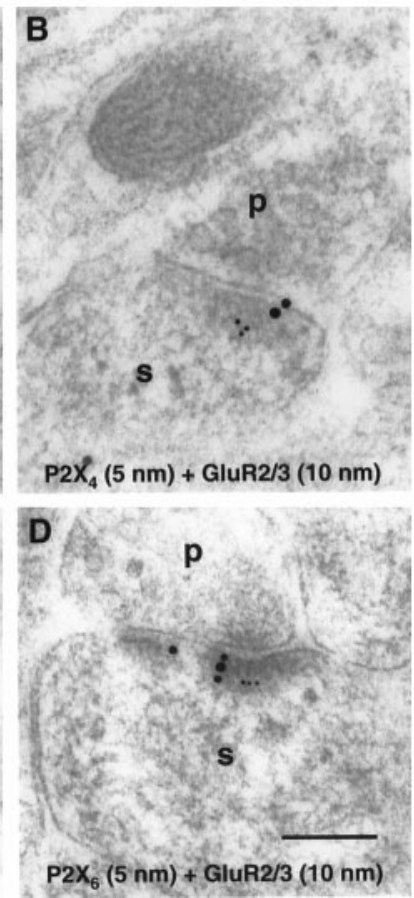

$\mathrm{P}_{2} \mathrm{X}_{4}(5 \mathrm{~nm})+\mathrm{GluR2} / 3(10 \mathrm{~nm})$

Figure 9. Electron micrographs showing double immunogold labeling for $\mathrm{P} 2 \mathrm{X}$ receptors subunits $(5 \mathrm{~nm})$ with GluR2/3 subunit of the AMPA type of glutamate receptors $(10 \mathrm{~nm})$ in cerebellum and hippocampus. Postsynaptic specializations of $\mathrm{PF}(A-C)$ in cerebellum and excitatory synapses in CA1 $(B-D)$ presented gold particles for both $\mathrm{P}^{2} \mathrm{X}_{4}(A-B)$ or $\mathrm{P}_{2} \mathrm{X}_{6}(C-D)$ with GluR2/3 $(A-D)$. $P F$, Parallel fibers; $p$, presynaptic; $s$, spine. Scale bar, $0.125 \mu \mathrm{m}$.

\section{Controls of immunogold labeling}

Several controls were performed at the light and electron microscopic level to ensure that the observed patterns of $\mathrm{P} 2 \mathrm{X}$ receptor distribution were specific. (1) The use of two primary antibodies to some subunits for both light and electron microscopy: antibodies to the same subunit always gave the same pattern of labeling. (2) The use of secondary antibodies coupled to two different sizes of gold particles ( 5 and $10 \mathrm{~nm}$ ) to determine ultrastructurally the distribution of $\mathrm{P} 2 \mathrm{X}$ receptors in cerebellum and hippocampus (Figs. 4, 7, and 10): the pattern of immunogold labeling was the same for both sizes of gold particles. (3) Omission of primary antibody in the first and sequential immunogold labeling and (4) preadsorption of primary antibody with the corresponding peptide conjugate or protein were performed for the antibodies to $\mathrm{P} 2 \mathrm{X}_{2}, \mathrm{P} 2 \mathrm{X}_{4}$, and $\mathrm{P} 2 \mathrm{X}_{6}$ subunits. Both procedures resulted in undetectable labeling in all cases. (5) To discard the possibility that the predominance of immunogold labeling at the peripheral portion of the postsynaptic specialization might be caused by unspecific clustering of the secondary antibody coupled to $5 \mathrm{~nm}$ gold particles, the distribution GluR2/3 subunits of AMPA receptors in cerebellum and hippocampus was determined (Fig. 11).

Table 2. Summary of the postembedding immunoreactivity for $\mathrm{P}_{2} \mathrm{X}_{2}, \mathrm{P}_{2} \mathrm{X}_{4}$, and $\mathrm{P} 2 \mathrm{X}_{6}$ in $\mathrm{CA1}$ stratum radiatum of the hippocampus

\begin{tabular}{llllr} 
Receptors & Number of PSDs & Average length of PSD $(\mu \mathrm{m})$ & $\begin{array}{l}\text { Average number of gold particles } \\
\text { per PSD (range) }\end{array}$ & $\begin{array}{l}\text { Number of gold particles per } \\
\text { micrometers of PSD } \pm \text { SEM }\end{array}$ \\
\hline P2X & 55 & $0.21 \pm 0.01$ & $1.5(0-9)$ & $8.7 \pm 1.8$ \\
P2X $_{4}$ & 63 & $0.20 \pm 0.01$ & $1.5(0-7)$ & $8.2 \pm 1.6$ \\
P2X $_{6}$ & 66 & $0.20 \pm 0.01$ & $2.1(0-8)$ & $12.6 \pm 1.8$
\end{tabular}

PSD: Postsynaptic specialization. 


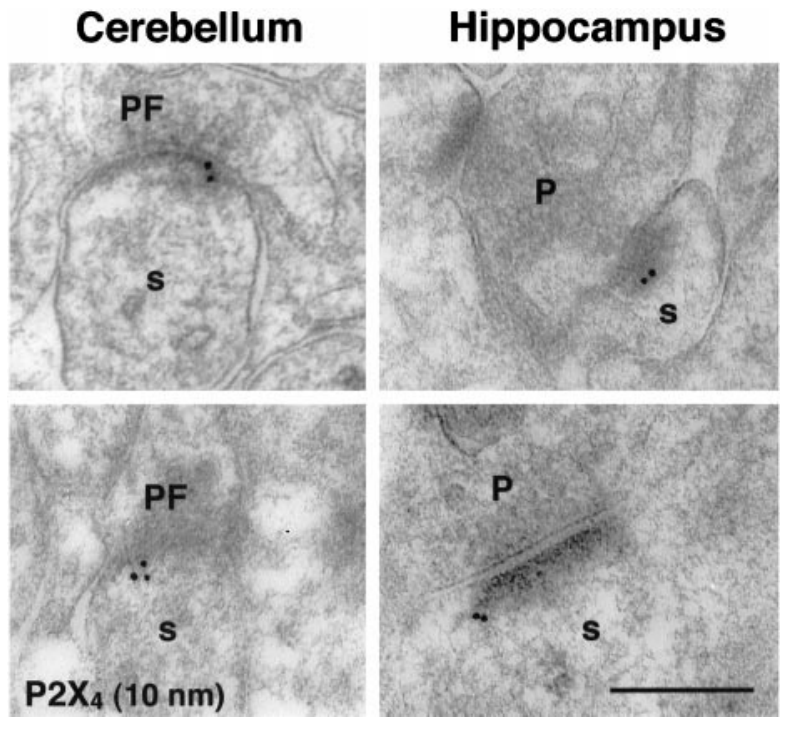

Figure 10. Electron micrographs showing postembedding immunogold labeling for $\mathrm{P} 2 \mathrm{X}_{4}$ subunits in cerebellum and hippocampus using $10 \mathrm{~nm}$ gold particles. Gold particles were observed at peripheral portions of cerebellar PF and CA1 hippocampal Schaffer collateral postsynaptic specializations. PF, Parallel fibers; $p$, presynaptic; $s$, spine. Scale bar, $0.250 \mu \mathrm{m}$.

Immunogold labeling was observed along excitatory postsynaptic specializations, presenting a distribution pattern similar to what has been shown previously for GluR2/3 receptors (Landsend et al., 1997; Rubio and Wenthold, 1997; Petralia et al., 1998; Takumy et al., 1999).

\section{DISCUSSION}

In this study we show that typical synapses that are considered glutamatergic on the basis of immunocytochemistry and ultrastructural characteristics express $\mathrm{P} 2 \mathrm{X}$ receptors. We describe for the first time, using a high-resolution anatomical technique, the precise subcellular localization of $\mathrm{P} 2 \mathrm{X}$ receptors in the CNS. P2X subunits are present at postsynaptic specializations of PF synapses in cerebellum and of Schaffer collateral synapses in hippocampus and may have a functional role in long-term depression and long-term potentiation, respectively. Analysis of their tangential distribution at the synapse showed that $\mathrm{P} 2 \mathrm{X}$ receptors are localized at peripheral portions of the postsynaptic specialization, where ionotropic glutamate receptor density drops off. Presence of $\mathrm{P} 2 \mathrm{X}$ receptor subunits at these excitatory synapses suggests an interaction between glutamatergic and purinergic transmission.

\section{Distribution of P2X subunits in cerebellum and hippocampus}

The expression of $\mathrm{P} 2 \mathrm{X}_{2}, \mathrm{P} 2 \mathrm{X}_{4}$, and $\mathrm{P} 2 \mathrm{X}_{6}$ mRNA transcripts in adult rat hippocampus and cerebellum has been documented (Buell et al., 1996; Collo et al., 1996; Séguéla et al., 1996; Soto et al., 1996a,b). Light microscopic immunostaining for $\mathrm{P} 2 \mathrm{X}_{2}$ and $\mathrm{P}_{2} \mathrm{X}_{4}$ on the cell bodies and dendrites of Purkinje and CA1 pyramidal cells has been presented (Lê et al., 1998b; Kanjhan et al., 1999; this study). Additionally, a presynaptic localization for $\mathrm{P} 2 \mathrm{X}_{2}$ was reported for synapses on the cell body and on dendrites of Purkinje cells (Kanjhan et al., 1999). No immunocytochemical data has been published on the distribution of $\mathrm{P} 2 \mathrm{X}_{6}$ subunits. With light microscopy, we found that immunolabeling for the three subunits is confined to cell bodies and dendrites, including dendritic spines of Purkinje and CA1 neurons, without indication
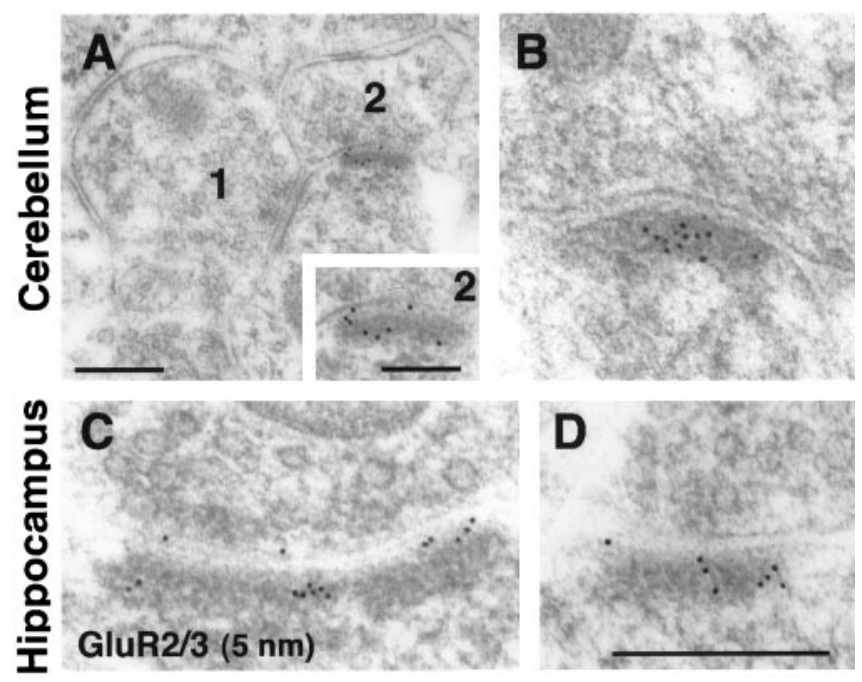

Figure 11. Electron micrographs showing postembedding immunogold labeling for GluR2/3 (5 nm gold particles) subunits of the AMPA glutamate receptors in cerebellum and hippocampus. Gold particles are observed distributed along the entire postsynaptic specialization of excitatory synapses $(A-D)$. A, A putative basket cell dendrite in the molecular layer of the cerebellum receiving inhibitory (1) and excitatory (2) synaptic inputs. Only the excitatory postsynaptic specialization (2) appears decorated with gold particles. Scale bars: $0.250 \mu \mathrm{m}$; inset, $0.125 \mu \mathrm{m}$.

of presynaptic labeling. Analysis of the axodendritic distribution of gold particles confirmed the preferential postsynaptic localization of the three subunits in both areas of the brain. No peak was detected indicating the existence of a presynaptic pool of receptors. Also, these data indicate that the epitopes are located at the cytoplasmic side of the postsynaptic specialization, pointing toward an intracellular localization of the $\mathrm{C}$ terminus, in agreement with the proposed topological model for P2X receptors (Newbolt et al., 1998; Torres et al., 1998b).

There is remarkable selectivity in the expression of $\mathrm{P} 2 \mathrm{X}_{2}$, $\mathrm{P} 2 \mathrm{X}_{4}$, and $\mathrm{P} 2 \mathrm{X}_{6}$ receptors in the cerebellar cortex. We found labeling on $\sim 50 \%$ of the Purkinje cell synapses that were apposed to $\mathrm{PF}$, whereas no labeling could be detected in $\mathrm{CF}$ and $\mathrm{BC}$ synapses, suggesting selective targeting of P2X subunits. A similar pattern of expression has been described for the $\delta 2$ subunit of glutamate receptors (Landsend et al., 1997; Zhao et al., 1998).

Overlapping patterns of expression for $\mathrm{P} 2 \mathrm{X}_{2}, \mathrm{P} 2 \mathrm{X}_{4}$, and $\mathrm{P} 2 \mathrm{X}_{6}$ in the CNS and synaptic localization of the three subunits in dendritic spines of the same cell type suggest heteromultimerization. $\mathrm{P} 2 \mathrm{X}_{2}$ and $\mathrm{P} 2 \mathrm{X}_{4}$ do not co-assemble when expressed in heterologous systems (Lewis et al., 1995; Torres et al., 1999). However, $\mathrm{P} 2 \mathrm{X}_{6}$ can assemble with both $\mathrm{P} 2 \mathrm{X}_{2}$ and $\mathrm{P} 2 \mathrm{X}_{4}$ subunits but cannot form functional homomultimeric receptors (Soto et al., 1996b; Lê et al., 1998a; Torres et al., 1999). Therefore, P2X receptors at excitatory synapses in hippocampus and cerebellum might be formed by homomeric $\mathrm{P} 2 \mathrm{X}_{2}$ or $\mathrm{P} 2 \mathrm{X}_{4}$ receptors or by heteromultimeric $\mathrm{P} 2 \mathrm{X}_{2} / \mathrm{P} 2 \mathrm{X}_{6}, \mathrm{P} 2 \mathrm{X}_{4} / \mathrm{P} 2 \mathrm{X}_{6}$ and $\mathrm{P} 2 \mathrm{X}_{2} / \mathrm{P} 2 \mathrm{X}_{4} / \mathrm{P} 2 \mathrm{X}_{6}$ combinations. The presence of $\mathrm{P} 2 \mathrm{X}_{1}$ receptors described in adult Purkinje cells by pre-embedding immunocytochemistry could add further complexity to the receptor composition (Loesch and Burnstock, 1998). However, the scarcity of $\mathrm{P}_{2} \mathrm{X}_{1}$ labeling in dendritic spines of Purkinje cells argues against a high percentage of $\mathrm{P} 2 \mathrm{X}$ receptors containing this subunit. Functional characterization of heterologously expressed $\mathrm{P} 2 \mathrm{X}_{2} / \mathrm{P} 2 \mathrm{X}_{4} / \mathrm{P} 2 \mathrm{X}_{6}$ receptors would help to correlate expression of subunits with physiological responses. 


\section{Functional implications of P2X receptors in cerebellum and hippocampus}

$\mathrm{P} 2 \mathrm{X}$ receptors permeable to $\mathrm{Ca}^{2+}$ and with a pharmacological behavior that resembles $\mathrm{P} 2 \mathrm{X}_{2}$ homomeric receptor have been described in Purkinje cells isolated from 7-d-old rats (Mateo et al., 1998). Studies of the single-channel properties of P2X receptors in rat cerebellar slices (3- to 7-d-old rats) suggest that receptors on Purkinje cells could be homomeric $\mathrm{P} 2 \mathrm{X}_{2}$ or $\mathrm{P} 2 \mathrm{X}_{4}$ receptors (Halliday and Gibb, 1997). However, possible differences in subunit composition between young and adults rats (Vulchanova et al., 1996; Kidd et al., 1998) and the lack of a dendritic tree of Purkinje neurons at that age (Altman and Bayer, 1997) make it difficult to compare the pharmacological data and the localization of P2X subunits described here.

ATP induces fast synaptic currents and an intracellular $\mathrm{Ca}^{2+}$ increase in cultured hippocampal neurons (Inoue et al., 1992, 1995). Moreover, ATP at low concentrations increases the amplitude of the population spike following the stimulation of Schaffer collaterals (Wieraszko and Seyfried, 1989). Experiments on hippocampal slices of 17- to 19-d-old rats have shown fast ATPmediated responses in CA1 neurons (Pankratov et al., 1998, 1999). EPSCs evoked by stimulation of Schaffer collaterals were not completely blocked by a combination of AMPA and NMDA receptor antagonists in $70 \%$ of the neurons tested. Low concentrations of the antagonist pyridoxal 5-phosphate 6-azophenyl$2^{\prime}, 4^{\prime}$ disulfonic acid (PPADS) blocked the remaining EPSCs in $60 \%$ of the neurons, indicating the presence of P2X receptormediated responses. Pharmacological characterization of the response to ATP using local application revealed a high variability of blockade by PPADS. Homomeric $\mathrm{P} 2 \mathrm{X}_{2}$ receptors are sensitive to PPADS (Evans et al., 1995), whereas homomultimeric P2X and heteromultimeric $\mathrm{P} 2 \mathrm{X}_{4} / \mathrm{P} 2 \mathrm{X}_{6}$ receptors are insensitive (Buell et al., 1996; Soto et al., 1996a; Lê et al., 1998a). Thus, variability in the subunit composition of the receptors might explain these differences in the pharmacological properties. The purinergic component of the response is apparently postsynaptic (Pankratov et al., 1998, 1999), notwithstanding a previous report in which ATP was proposed to act presynaptically to increase glutamate release from Schaffer collaterals (Motin and Bennett, 1995). Our data are in concordance with a postsynaptic action of ATP at Schaffer collateral synapses.

Heterologously expressed homomeric $\mathrm{P} 2 \mathrm{X}_{2}$ and $\mathrm{P} 2 \mathrm{X}_{4}$ receptors are more permeable to $\mathrm{Ca}^{2+}$ than to monovalent cations. Likewise, P2X receptors present in neurons have a significant permeability to $\mathrm{Ca}^{2+}$ (Burnashev, 1998). For instance, P2X receptors in sympathetic ganglion cells have a permeability ratio $\left(\mathrm{P}_{\mathrm{Ca}^{2}+} / \mathrm{P}_{\mathrm{Na}^{+}}\right)$of 5, whereas a permeability ratio of $>10$ has been described for some neurons of the medial habenula nucleus (Edwards et al., 1997). An increase on $\left[\mathrm{Ca}^{2+}\right]_{\mathrm{i}}$ has been related to hippocampal long-term potentiation and cerebellar long-term depression (Denk et al., 1995; Nicoll and Malenka, 1995). In cerebellum it was shown recently that high-frequency stimulation of PF can change the composition of AMPA receptors at stellate cell dendrites by controlling the expression or targeting of edited subunits (Liu and Cull-Candy, 2000). Increases in $\left[\mathrm{Ca}^{2+}\right]_{i}$ produced by the activation of $\mathrm{Ca}^{2+}$-permeable AMPA receptors may be necessary for the alteration in receptor composition. We have found immunogold labeling for P2X receptor subunits on stellate cell dendrites postsynaptic to PF (our unpublished results). The slow decay kinetics of ATP-mediated EPSCs (time constant $30 \mathrm{msec}$ ) (Edwards et al., 1992; Evans et al., 1992;
Pankratov et al., 1998, 1999), the high $\mathrm{Ca}^{2+}$ permeability of P2X receptors, and their localization at appropriate sites suggest a further role for P2X receptors in the synaptic plasticity of these cells.

\section{$\mathrm{P} 2 \mathrm{X}$ receptors at excitatory postsynaptic specializations}

In the present study we report the presence of $\mathrm{P} 2 \mathrm{X}$ receptors as a new component at glutamatergic postsynaptic specializations. Moreover, by analyzing the tangential distribution of gold particles we found that $\sim 90 \%$ of P2X receptors are located at the peripheral portions of the synaptic disk. With few exceptions [cochlea: Matsubara et al. (1996); neostriatum: Bernard et al. (1997)], the density of ionotropic glutamate receptors decreases at the peripheral portions of the postsynaptic membrane (Kharazia and Weinberg, 1997; Landsend et al., 1997; Petralia et al., 1998; Nusser, 1999). This distribution of glutamate receptors could be necessary for an effective response to glutamate and may be modified through synaptic plasticity (Edwards, 1995). Similarly, the location of P2X receptors at the peripheral portion of the postsynaptic specialization might be necessary to assure the response to ATP in two ways. First, $\mathrm{Ca}^{2+}$ entry through P2X receptors might activate a subset of intracellular second messengers by being located at the peripheral portion of the postsynaptic specialization. Second, P2X receptors could be close to the ATP releasing sites. In CNS, ATP can be co-released with GABA in the spinal cord (Jo and Schlichter, 1999) and with noradrenaline in the locus coeruleus (Nieber et al., 1997). ATP is not coreleased with glutamate in the medial habenula (Robertson and Edwards, 1997). However, co-release of glutamate and ATP from Schaffer collaterals and/or PF, or both, cannot be discarded. Glia can influence neuronal activity by releasing biologically active substances (Kang et al., 1998). For instance, ATP is released during $\mathrm{Ca}^{2+}$ waves (Cotrina et al., 1998; Guthrie et al., 1999) and after activation of glutamate receptors (Clark and Barbour, 1997; Querioz et al., 1997; Dzubay and Jahr, 1999; Bergles et al., 2000). As we have shown in this study $\mathrm{P} 2 \mathrm{X}_{2}, \mathrm{P}_{2} \mathrm{X}_{4}$, and $\mathrm{P} 2 \mathrm{X}_{6}$ subunits are concentrated at peripheral portions of postsynaptic specializations of PF and of Schaffer collaterals, in close relationship with glial processes. The distance between glial processes and $\mathrm{P} 2 \mathrm{X}$ receptors is in the range of $20-100 \mathrm{~nm}$, and the theoretical distance at which diffusing ATP would remain above $100 \mathrm{~nm}$ is $100 \mu \mathrm{m}$ [see discussion by Guthrie et al. (1999)]. Thus, our data suggest that postsynaptic $\mathrm{P} 2 \mathrm{X}$ receptors are close enough to glial processes to be activated by ATP released from glial cells.

\section{REFERENCES}

Altman J, Bayer SA (1997) Development of cerebellar system in relation to its evolution, structure and functions. New York: CRC.

Bardoni R, Goldstein PA, Lee CJ, Gu JG, McDermott AB (1997) ATP $\mathrm{P} 2 \mathrm{X}$ receptors mediate fast synaptic transmission in the dorsal horn of the rat spinal cord. J Neurosci 17:5297-5304.

Bergles DE, Roberts JD, Somogyi P, Jahr CE (2000) Glutamatergic synapses on oligodendrocyte precursor cells in the hippocampus. Nature 405:187-191.

Bernard V, Somogyi P, Bolam JP (1997) Cellular, subcellular, and subsynaptic distribution of AMPA-type glutamate receptor subunits in the neostriatum of the rat. J Neurosci 17:819-833.

Brake AJ, Wagenbach MJ, Julius D (1994) New structural motif for ligand-gated ion channels defined by an ionotropic ATP receptor. Nature 371:519-523.

Buell G, Lewis C, Collo G, North RA, Surprenant A (1996) An antagonist-insensitive $\mathrm{P} 2 \mathrm{X}$ receptor expressed in epithelia and brain. EMBO J 15:55-62.

Burnashev N (1998) Calcium permeability of ligand-gated channels. Cell Calcium 24:325-332.

Burnstock G (1999) Current status of purinergic signalling in the nervous system. Prog Brain Res 120:3-10. 
Chen C, Okoyama H (1987) High-efficiency transformation of mammalian cells by plasmid DNA. Mol Cell Biol 7:2745-2752.

Clark BA, Barbour B (1997) Currents evoked in Bergmann glial cells by parallel fiber stimulation in rat cerebellar slices. J Physiol (Lond) 502:335-350.

Collo G, North RA, Kawashima E, Merlo-Pich E, Neidhart S, Surprenant A (1996) Cloning of P2X5 and P2X6 receptors and the distribution and properties of an extended family of ATP-gated ion channels. J Neurosci 16:2495-2507.

Cotrina ML, Lin JH, Nedergaard M (1998) Cytoskeletal assembly and ATP release regulate astrocytic calcium signalling. $\mathrm{J}$ Neurosci 18:8794-8804.

Denk W, Sugimori M, Llinas R (1995) Two types of calcium response limited to single spines in cerebellar Purkinje cells. Proc Natl Acad Sci USA 92:8279-8282.

Dubyak GR, el-Moatassim C (1993) Signal transduction via P2purinergic receptors for extracellular ATP and other nucleotides. Am J Physiol 265:C577-606.

Dzubay JA, Jahr CE (1999) The concentration of synaptically released glutamate outside of the climbing fiber-Purkinje cell synaptic cleft. J Neurosci 19:5265-5274.

Edwards FA (1995) LTP: a structural model to explain the inconsistencies. Trends Neurosci 18:250-255.

Edwards FA, Gibb AJ (1993) ATP: a fast neurotransmitter. FEBS Lett 325:86-89.

Edwards FA, Gibb AJ, Colquhoun D (1992) ATP receptor-mediated currents in the central nervous system. Nature 359:144-147.

Edwards FA, Robertson SJ, Gibb A (1997) Properties of ATP receptormediated synaptic transmission in the rat medial habenula. Neuropharmacology 9:1253-1268.

Evans RJ, Derkach V, Surprenant A (1992) ATP mediates fast synaptic transmission in mammalian neurons. Nature 357:503-505.

Evans RJ, Lewis C, Buell G, Valera S, North RA, Surprenant A (1995) Pharmacological characterization of heterologously expressed ATPgated cation channels (P2X purinoceptors). Mol Pharmacol 48:178-183.

Garcia-Guzman M, Soto F, Gomez-Hernandez JM, Lund PE, Stühmer W (1997) Characterization of recombinant human P2X4 receptor reveals pharmacological differences to the rat homologue. Mol Pharmacol 51:109-118.

Guthrie PB, Knappenberger J, Segal M, Bennett MVL, Charles AC, Kater SB (1999) ATP released from astrocytes mediates glial calcium waves. J Neurosci 19:520-528.

Halliday FC, Gibb AJ (1997) Single-channel properties of P2X ATP receptors in rat cerebellar slices. J Physiol (Lond) 504.P:51.P.

Hayat MA (1989) Colloidal gold. Principles, methods and applications. London: Academic.

Holton P (1959) The liberation of adenosine triphosphate on antidromic stimulation of the sensory nerves. J Physiol (Lond) 145:491-504.

Inoue K, Nakazawa K, Fujimori W, Watano W, Takanaka A (1992) Extracellular adenosine $5^{\prime}$-triphosphate-evoked glutamate release in cultured rat hippocampal neurons. Neurosci Lett 134:215-218.

Inoue K, Koizumi S, Nakazawa K (1995) Glutamate-evoked release of adenosine $5^{\prime}$-triphosphate causing an increase in intracellular calcium in hippocampal neurons. NeuroReport 6:437-440.

Jo Y, Schlichter R (1999) Synaptic corelease of ATP and GABA in cultured spinal neurons. Nat Neurosci 2:241-245.

Kang J, Jiang L, Goldman SA, Nedergaard M (1998) Astrocytemediated potentiation of inhibitory synaptic transmission. Nat Neurosci 1:683-692.

Kanjhan R, Housley GD, Burton LD, Christie DL, Kippenberger A, Thorne PR, Luo L, Ryan AF (1999) Distribution of the P2X receptor $_{2}$ subunit of the ATP-gated ion channels in the rat central nervous system. J Comp Neurol 407:11-32.

Kharazia VN, Weinberg RJ (1997) Tangential synaptic distribution of NMDA and AMPA receptors in rat neocortex. Neurosci Lett 238:41-44.

Kidd EJ, Grahames CBA, Simon J, Michel AD, Barnard EA, Humphrey PPA (1995) Localization of P2X purinoceptor transcripts in the rat nervous system. Mol Pharmacol 48:569-573.

Kidd EJ, Miller KJ, Sansum AJ, Humphrey PPA (1998) Evidence for P2X3 receptors in the developing rat brain. Neuroscience 87:533-539.

Landsend AS, Amry-Mogaddam M, Matsubara A, Bergersen L, Usami S, Wenthold RJ, Ottersen OP (1997) Differential localization of $\delta$ glutamate receptors in the rat cerebellum: co-expression with AMPA receptors in parallel fiber-spine synapses and absence from climbing fiber-spine synapses. J Neurosci 17:834-842.

Lê K-T, Babinski K, Séguéla P (1998a) Central P2X4 and P2X6 channel subunits coassemble into a novel heteromeric ATP receptor. J Neurosci 18:7152-7159.

Lê K-T, Villeneuve P, Ramjaun AR, McPherson PS, Beaudet A, Séguéla P (1998b) Sensory presynaptic and widspread somatodendritic immunolocalization of central ionotropic P2X ATP receptors. Neuroscience 83:177-190.
Lewis C, Neidhart S, Holy C, North RA, Buell G, Surprenant A (1995) Coexpression of $\mathrm{P} 2 \mathrm{X} 2$ and $\mathrm{P} 2 \mathrm{X} 3$ receptor subunits can account for ATP-gated currents in sensory neurons. Nature 377:432-435.

Liu S-QJ, Cull-Candy S (2000) Synaptic activity at calcium permeable AMPA receptors induces a switch in receptor subtype. Nature 405:454-457.

Loesch A, Burnstock G (1998) Electron-immunocytochemical localization of $\mathrm{P} 2 \mathrm{X} 1$ receptors in the rat cerebellum. Cell Tissue Res 294:253-260.

Mateo J, Garcia-Lecea M, Miras-Portugal MT, Castro E (1998) Ca ${ }^{2+}$ signals mediated by P2X-type purinoreceptors in culture cerebellar Purkinje cells. J Neurosci 18:1704-1712.

Matsubara A, Laake JH, Davanger S, Usami S, Ottersen OP (1996) Organization of AMPA receptor subunits at a glutamate synapse: a quantitative immunogold analysis of hair cell synapses in rat organ of Corti. J Neurosci 16:4457-4467.

Merighi A, Polak JM (1993) Postembedding immunogold staining. In: Immunocytochemistry II (Cuello AC, ed), pp 229-264. New York: Wiley.

Motin L, Bennett MR (1995) Effect of P2-purinoceptor antagonists on glutamatergic transmission in the rat hippocampus. $\mathrm{Br} \mathrm{J}$ Pharmacol 115:1276-1280.

Mugnaini E (1972) The histology and cytology of the cerebellar cortex. In: The comparative anatomy and histology of the cerebellum: the human cerebellum, cerebellar connections, and cerebellar cortex (Larsell O, Jansen J, eds) pp 201-251. Minneapolis: University of Minesota.

Newbolt A, Stoop R, Virginio C, Surprenant A, North RA, Buell G, Rassendren F (1998) Membrane topology of an ATP-gated ion channel (P2X receptor). J Biol Chem 273:15177-15182.

Nicoll RA, Malenka RC (1995) Contrasting properties of two forms of long-term potentiation in the hippocampus. Nature 377:115-118.

Nieber K, Poelchen W, Illes P (1997) Role of ATP in fast excitatory synaptic potentials in locus coeruleus neurones of the rat. Br J Pharmacol 122:423-430.

North RA, Barnard E (1997) Nucleotide receptors. Curr Opin Neurobiol 7:346-357.

Nusser Z (1999) Subcellular distribution of neurotransmitter receptors and voltage-gated ion channels. In: Dendrites (Stuart G, Spruston N, Häusser M, eds), pp 85-113. London: Oxford UP.

Palay SL, Chan-Palay V (1974) Cerebellar cortex. New York: Springer.

Pankratov Y, Castro E, Miras-Portugal MT, Krishtal O (1998) A purinergic component of the excitatory postsynaptic current mediated by $\mathrm{P} 2 \mathrm{X}$ receptors in the CA1 neurons of the rat hippocampus. Eur J Neurosci 10:3898-3902.

Pankratov Y, Lalo U, Castro E, Miras-Portugal MT, Krishtal O (1999) ATP receptor-mediated component of the excitatory synaptic transmission in the hippocampus. Prog Brain Res 120:237-249.

Peters A, Palay SL, Webster H de F (1991) The fine structure of the nervous system. Neurons and supporting cells. New York: Oxford UP.

Petralia RS, Zhao H-M, Wang Y-X, Wenthold RJ (1998) Variations in the tangential distribution of postsynaptic glutamate receptors in Purkinje cell parallel and climbing fiber synapses during development. Neuropharmacology 37:1321-1334.

Querioz G, Gebicke-Haerter PJ, Schobert A, Starke K, Kügelgen IV (1997) Release of ATP from cultured rat astrocytes elicited by glutamate receptor activation. Neuroscience 78:1203-1208.

Racca C, Stephenson FA, Streit P, Roberts JDB, Somogyi P (2000) NMDA receptor content of synapses in stratum radiatum of the hippocampal CA1 area. J Neurosci 20:2512-2522.

Robertson SJ (1998) Tissue distribution and functional contribution of P2X receptors in the CNS. Drug Dev Res 45:336-341.

Robertson SJ, Edwards FA (1997) ATP and glutamate are released from separate neurons in the rat medial habenula nucleus: frequency dependence and adenosine-mediated inhibition of release. J Physiol (Lond) 503:691-701.

Rubio ME, Wenthold RJ (1997) Glutamate receptors are selectively targeted to postsynaptic sites in neurons. Neuron 18:939-950.

Rubio ME, Wenthold RJ (1999) Differential distribution of intracellular glutamate receptors in dendrites. J Neurosci 19:5549-5562.

Sassoè-Pognetto M, Ottersen P (2000) Organization of ionotropic glutamate receptors at dendrodendritic synapses in the rat olfactory bulb. J Neurosci 20:2192-2201.

Séguéla P, Haghighi A, Soghomonian JJ, Cooper E (1996) A novel neuronal P2X ATP receptor channel with widespread distribution in the brain. J Neurosci 16:448-455.

Smith DB, Corcoran LM (1995) Expression and purification of glutathione- $S$-transferase fusion proteins. In: Current protocols in molecular biology, Vol 2 (Ausubel FM, Brent R, Kingston RE, Moore DD, Seidman JG, Smith JA, Struhl K, eds), pp 16.7.1-16.7.7. New York: Wiley.

Soto F, Garcia-Guzman M, Gomez-Hernandez JM, Hollmann M, Karschin C, Stühmer W (1996a) P2X4: and ATP-activated ionotropic receptor cloned from rat brain. Proc Natl Acad Sci USA 93:3684-3688. 
Soto F, Garcia-Guzman M, Karschin C, Stühmer W (1996b) Cloning and tissue distribution of a novel $\mathrm{P} 2 \mathrm{X}$ receptor from rat brain. Biochem Biophys Res Commun 223:456-460.

Soto F, Garcia-Guzman M, Stühmer W (1997) Cloned ligand-gated channels activated by extracellular ATP (P2X receptors). J Membr Biol 160:91-100.

Takayama C, Nakagawa S, Watanabe M, Mishina M, Inoue Y (1996) Developmental changes in expression and distribution of the glutamate receptor $\delta 2$ subunit according to the Purkinje cell maturation. Dev Brain Res 92:147-155.

Takumy Y, Ramírez-León V, Laake P, Rinvik E, Ottersen OP (1999) Different modes of expression of AMPA and NMDA receptors in hippocampal synapses. Nat Neurosci 2:618-624.

Torres GE, Egan TM, Voigt MM (1998a) N-linked glycosylation is essential for the functional expression of the recombinant $\mathrm{P} 2 \mathrm{X} 2$ receptor. Biochemistry 37:14845-14851.

Torres GE, Egan TM, Voigt MM (1998b) Topological analysis of the ATP-gated ionotropic P2X2 receptor subunit. FEBS Lett 425:19-23.

Torres GE, Egan TM, Voigt MM (1999) Hetero-oligomeric assembly of
P2X receptor subunits. Specificities exist with regard to possible partners. J Biol Chem 274:6653-6659.

Valera S, Hussy N, Evans RJ, Adami N, North RA, Surprenant A, Buell G (1994) A new class of ligand-gated ion channel defined by P2X receptor for extracellular ATP. Nature 371:516-519.

Ventura R, Harris KM (1999) Three-dimensional relationships between hippocampal synapses and astrocytes. J Neurosci 19:6897-6906.

Vulchanova L, Arvidsson U, Riedl M, Wang J, Buell G, Surprenant A, North RA, Elde R (1996) Differential distribution of two ATP-gated ion channels (P2X receptors) determined by immunoytochemistry. Proc Natl Acad Sci USA 93:8063-8067.

Wenthold RJ, Yokotani N, Doi K, Wada K (1992) Immunochemical characterization of the non-NMDA glutamate receptor using subunitspecific antibodies. J Biol Chem 267:501-507.

Wieraszko A, Seyfried TN (1989) Stimulation-dependent release of adenosine triphosphate from hippocampal slices. Brain Res 485:244-250.

Zhao H, Wenthold RJ, Petralia RS (1998) Glutamate receptor targeting to synaptic populations on Purkinje cells is developmentally regulated. J Neurosci 18:5517-5528. 